\title{
Ruptura del concubinato y reparación civil
}

Yuri Vega Mere*

\section{El golpe dado por las cifras}

Guste o no, la ausencia de una regulación amplia y detallada respecto de la familia no matrimonial traduce un claro propósito de ignorar una realidad que nos circunda.

Cualquier intento de dar mayor presencia en la ley a la unión convivencial infunde temor al legislador: temor de ir en contra de costumbres, dogmas, principios, conceptos o, finalmente, electores. Este temor se extiende a la escasa doctrina y a la tímida jurisprudencia.

Un dato curioso: en realidades como las nuestras, el matrimonio religioso se vive con más fervor que el matrimonio civil. A este no se va ni se sale de blanco; a este no van las amistades; este no causa impacto. Es probable que un elevado número de parejas se sientan casadas por haber recibido la aprobación de alguna autoridad del culto que profesan y no por haber escuchado la usualmente tediosa y apresurada lectura de algunas normas del Código Civil de boca de algún funcionario del registro del estado civil. Sin duda, sería interesante contar con la opinión de los psicólogos y de los sociólogos sobre este hecho que, muy probablemente, provenga de nuestras creencias o de la presión del medio.

A pesar de esta constatación, la unión de hecho ha comenzado a tener mayor aceptación, especialmente en otras latitudes. Los datos que Francis Fukuyama proporciona en su obra La gran ruptura son notables. Al analizar los cambios familiares y el incremento de las tasas de hijos no matrimoniales, Fukuyama da cuenta del incremento de la cohabitación en los países europeos. Según indica, entre los 20 y 24 años, el $45 \%$ de las mujeres 
danesas, el $44 \%$ de las mujeres suecas y el $19 \%$ de las mujeres holandesas viven con pareja sin haber contraído matrimonio, mientras que, en los Estados Unidos, el hecho alcanza solo al $14 \%$ de las mujeres. En este último país, alrededor del $25 \%$ de todos los nacimientos extramatrimoniales corresponde a parejas que conviven; en Francia, Dinamarca o en Holanda, esta proporción es mucho más alta; y, en Suecia, alcanza casi el 90\% de los nacimientos. Según refiere el futurólogo, los observadores coinciden en que la sustitución del matrimonio por la cohabitación de la pareja ha sido sustancial. En Suecia, la tasa de matrimonios es tan baja (3,6 habitantes de cada 1.000) que se podría decir que se trata de una institución en crisis que se mantendrá por mucho tiempo. ${ }^{1}$ Para este pensador posmoderno, si bien la ilegitimidad de los nacimientos se asocia con la pobreza, en los países occidentales, fenómenos como el divorcio y la cohabitación se encuentran más difundidos entre individuos de clase media y clase alta. ${ }^{2}$

En el Perú, las cifras registradas por el Instituto Nacional de Estadística e Informática (INEI) en 1993 (año en el que se realizó el último censo) son de sumo interés. ${ }^{3}$ De un total de 15.483 .790 personas censadas en las áreas urbana y rural, 2.488.779 de personas se encontraban unidas en convivencia sin matrimonio, mientras que 5.384.534 individuos fueron censados como casados. Existe un número de personas solteras que asciende a 6.481.083, dentro de las cuales, probablemente, algunas han silenciado cohabitar con una pareja y un grueso de 176.495 no ha especificado su estado civil (si en este concepto se incluye, como lo hace el INEI, a los convivientes). Ello equivale a decir que el $16,07 \%$ de la población total del Perú, en 1993, fue registrado como conviviente, mientras que $33,77 \%$ se reportó como casado. A tales datos debemos añadir que, en la misma época, 617.750 personas manifestaron ser viudas; 65.654, divorciadas; y 269.495, separadas, es decir, la preferencia por el matrimonio se mostraba como mayoritaria, dado que 6.337 .433 personas del total censado, o sea, un $40,92 \%$ de la población del Perú, habían sido parte de un matrimonio hasta el año 1993. Sin embargo, el porcentaje de concubinatos no aparecía como un dato carente de significado.

Si tomamos únicamente el área urbana, encontramos que, en ella, de un total de 11.279.624 personas censadas en 1993, 1.561 .853 vivían en concubinato $(13,84 \%$ de la población urbana), en tanto que 3.965 .167 (35.15\% de la población urbana) se registraron como casadas con matrimonio vigente a dicha fecha. A estos números se debe adicionar las cifras de los viudos

FUKUYAMA, Francis. La gran ruptura. Buenos Aires: Atlándida, 1999, pp. 68-73.

Ib., p. 105.

Datos en <http://www.inei.gob.pe>. 
(397.907), divorciados (56.881) y separados (216.627). En términos reales, en el área urbana, el $41.10 \%$ de los individuos eligió el matrimonio como forma de constitución de una familia frente al $13.84 \%$ que cohabitaba sin previas nupcias.

En el ámbito rural, de un total de 4.204.166 personas, 926.926 (o sea, el $22,90 \%$ ) eran convivientes y 1.419 .367 individuos (es decir, el 33,76\%) manifestaron ser casados. Es claro que, aun cuando las cifras tienen más de una década de registradas, los niveles de las familias no casadas eran mayores en el área rural. Del mismo modo que en los casos anteriores, no se puede pasar por alto a las personas viudas, que llegaron a las 219.843; a los divorciados, que eran 8.773; y a los separados, que fueron del orden de las 52.868 personas. Como resultado, en el área rural, el 40,45\% de la población creyó en el matrimonio hasta en dicha oportunidad, frente a un 22,90\% que optó por la cohabitación sin papeles.

Los índices de convivencia también se pueden verificar por el sexo de las personas. Mientras que, de un total de 7.626.084 de hombres, 1.199.914 varones manifestaron tener una convivencia more uxorio, 2.632.296 habían optado por el matrimonio. El 15,73\% prefirió el concubinato, frente a un $34,51 \%$ que eligió la unión conyugal. También contrajeron matrimonio los viudos (157.813), los divorciados (25.880) y los separados (71.810). Como cifra final, el $37,86 \%$ de los hombres había seguido el camino del matrimonio y el $15,73 \%$ no.

En cambio, entre las mujeres, de una cifra de 7.857.706, un número de 1.288 .865 prefirió la convivencia sin papeles (el 16,40\%), frente a 2.752.238 (el 35,02\%), que pasaron por la ceremonia matrimonial. Igualmente, se aprecia la existencia de un matrimonio previo o no disuelto en las mujeres viudas (459.937), divorciadas (39.774) y separadas (197.685). A esa fecha, el 43,90\% de las mujeres creía o había creído en el matrimonio, frente a un $16,40 \%$ que no consideró necesario celebrar ceremonia alguna para crear una familia.

En el año 2000, el INEI realizó encuestas demográficas y de salud familiar que también arrojaron algunas cifras interesantes. ${ }^{4}$ De acuerdo con los datos recolectados, el $25 \%$ de las mujeres en edad fértil conviven sin estar unidas por matrimonio.

Las estadísticas no distinguen el tipo de matrimonio, pero se asume que es el civil y no el religioso.

En resumen, al año 1993 el 16,07\% de la población del Perú vivía en concubinato, es decir, alrededor de la sexta parte de la misma. Y, si la referencia

Encuesta Demográfica y de Salud Familiar. Instituto Nacional e Informática. Resumen ejecutivo, p. 11. 
que se toma es la de las mujeres en edad fértil, el porcentaje de convivientes es, al año 2000, del 25\% (es claro que esas mujeres conviven con un número similar de varones en edad reproductiva). No tenemos, desafortunadamente, cifras oficiales que abarquen a toda la población de más reciente data, pero los números son importantes y, por ello, el tema no puede ser ignorado por más tiempo. Es probable que, debido a la mayor tolerancia con que hoy en día se mira a los concubinatos, aquel porcentaje pueda haberse incrementado.

Las cifras, por otro lado, deberían instar a cualquier investigador de toda ciencia social (léase sociólogos, antropólogos, juristas, etc.) a preguntarse qué es lo que viene ocurriendo. Las estadísticas, que le toman el pulso a la realidad, deben instarnos a reflexionar.

\section{El matrimonio como modelo excluyente}

El modelo familiar elegido por el legislador se sustenta en el matrimonio, pese a que la unión de hecho es históricamente más antigua. Ya hemos señalado, en otra oportunidad, ${ }^{5}$ que, debido a que la familia genera una serie de relaciones (entre la pareja, entre la pareja y los hijos, y entre la pareja y terceros), ellas no pueden quedar libradas siempre, in toto, a la decisión de los propios interesados, especialmente en lo atinente a los derechos personales. Se requiere de un adecuado estatuto que garantice derechos y deberes entre los componentes del grupo familiar y de pautas ciertas que protejan a los extraños que establecen relaciones con aquellos. Además, es fundamental que se propenda a la efectiva realización de tales derechos, con niveles mínimos de protección cuyo objetivo final no es otro que garantizar el bien común. ${ }^{6}$ Esta tarea ha sido asumida por el Estado y, para ello, tomó como sustrato de la familia a aquella basada en el matrimonio.

El modelo de familia protegido por el Estado se construyó sobre la base de la fusión entre el matrimonio romano y el derecho canónico. Debido al caos existente en el medioevo, derivado de la confrontación de normas aplicables a los individuos, de la informalidad de las uniones entre varones y mujeres, así como del ejercicio libre y hasta incontrolado de la sexualidad, la Iglesia católica, a través del Concilio de Trento (Sesión XXIV, del 11 de noviembre de 1563), impuso la obligación de formalizar las uniones entre

VEGA MERE, Yuri. "La eclosión de las legislaciones protectivas de las uniones homosexuales». Revista Jurídica del Perú, agosto, 2002, pp. 234-235, Trujillo.

6 LENSEL, Denis y Jacques LAFOND. La famille a venir. Une realité menacé mais nécessaire. París: Economica, 2000, p. 27 y ss. 
varón y mujer ante la autoridad eclesiástica como único medio de legitimación de las familias. Con ello, los concubinatos fueron proscritos y los concubinos fueron condenados a la excomunión. ${ }^{7}$ Por entonces, el matrimonio era únicamente un sacramento que debía sujetarse a los ritos católicos.

Si bien con la aparición de la burguesía se arrebató la exclusividad del matrimonio a la Iglesia, pues entonces se abrió camino a su secularización, el matrimonio civil no dejó de ser el único medio exclusivo para reconocer legalidad a los grupos familiares y como único sustrato para el reconocimiento de derechos de naturaleza familiar.

El sistema legal liberal plasmado en los viejos códigos civiles, empero, muestra una paradoja. Por un lado, el derecho civil de la «modernidad» fue edificado sobre la base de una racionalidad lógica formal que se expresaba en la elaboración de conceptos autosuficientes que creasen un sistema legal seguro, predictible, que permitiera conocer anticipadamente las reglas de juego a los agentes económicos, un sistema que se acoplase armoniosamente con la necesidad de construir una sociedad que terminase con los particularismos y se convirtiese en una sociedad homogénea en cuyo interior los bienes y servicios fuesen fácilmente intercambiables por individuos movidos por sus propios intereses. A estos individuos, precisamente, el nuevo sistema les reconoció considerables espacios de autonomía para el juego de sus transacciones, que calzaban con el naciente capitalismo signado por la racionalidad utilitaria. ${ }^{8}$

Pero, por otro lado, y específicamente en el terreno familiar, el derecho liberal fue excesivamente rígido. Si la familia no se basaba en el matrimonio, no merecía el favor del legislador. Por ello, se ha dicho con razón que el derecho familiar liberal fue excluyente; ${ }^{9}$ quiso, como producto de la modernidad, ser uniforme, aun a costa de desconocer la realidad de las situaciones maritales no matrimoniales, a las cuales simplemente condenó al ostracismo. Las palabras de Napoleón, al intervenir en los debates de lo que luego se convertiría en el Código Civil de los franceses, fueron elocuentes: «Si los concubinos ignoran la ley, la ley los ignora» («Puisque les concubins se désintéressent de la loi, la loi n'a qu’à se désintéresser d'eux»). La convivencia more coniugali, de esa manera, de haber sido una realidad fáctica casi mayoritaria hasta la llegada del Concilio de Trento, gracias al pacto implícito

Cornejo Chávez, Héctor. Derecho familiar peruano. Lima: Gaceta Jurídica, 1999, p. 65.

8 Véase TRAzegnies Granda, Fernando de. Postmodernidad y derecho. Lima: Ara Editores, 1996, pp. 21-31.

9 SILVEIRA RAMOS, Carmen Lucía. Familia sem casamento: de relaçâo existencial de fato a realidade jurídica. Río de Janeiro: Renovar, 2000, pp. 46-48, 57 y ss. 
entre Estado e Iglesia (quizá como una forma de ganarse la simpatía de esta última al haber laicalizado el matrimonio), pasó a ser vista como un situación censurable, inmoral, ajena al derecho, contraria a la ley, al grado de consagrarse una abierta discriminación contra los hijos no matrimoniales, a los cuales se les regaló el distintivo de bastardos.

El Estado optó por reglas claras pero monolíticas que privaron de una fuerte dosis de autonomía a los individuos respecto de las decisiones de orden convivencial y familiar.

\section{Razones de la hostilidad hacia la familia de hecho}

El modelo de familia que ha prevalecido por años no es producto del azar. A su conformación ha confluido una serie de factores que muestran que la familia, aun siendo una institución que se sustenta, fundamentalmente, en lazos de orden biológico y en razones de orden social y hasta emocional, tarde o temprano se puede ver envuelta en una definición de tipo legal que implica, de suyo, la elección de un "modelo» de familia.

A partir de esa opción, que proviene del Estado (no sin consultar lo que acontece al interior de las convicciones sociales y éticas mayoritariamente aceptadas), se organiza toda una urdimbre de vinculaciones jurídicas, ya sea de orden personal o patrimonial entre los miembros del grupo familiar. Si bien la ley no puede ir en contra de hechos que tengan una raíz biológica, el sistema legal es el que, desde que asume un modelo, determina los derechos y obligaciones de cada uno de los componentes de la familia, establece su funcionamiento interno, norma el régimen de bienes y su administración, prevé las formas de asistencia y de suplir las carencias, fija las condiciones de separación y ruptura, etc. ${ }^{10}$

El Estado, se ha dicho, requiere de alguna forma de organización de los individuos. Siendo la familia (no el «modelo») una institución connatural al ser humano y una suerte de bisagra entre el individuo y la sociedad, su encuadramiento legal intenta juridificar las relaciones que se generan entre sus integrantes, con propósitos de organización y orden, ${ }^{11}$ decíamos, cuando no con una función garantista de los derechos de sus miembros, y, también, como una forma de canalizar la sexualidad de las personas, asunto que

10 Trazegnies GRANDA, Fernando de. "La familia, ¿un espejismo jurídico?». En La familia en el derecho peruano. Libro homenaje al doctor Héctor Cornejo Chávez. Lima: Pontificia Universidad Católica del Perú, 1992, p. 21 y ss., especialmente 37 y ss.

11 ADEZATI, Giovanni. "Nuove unioni e nuovi status». En Francesca Brunetta d'Usseaux y Antonino d'Angelo (eds.). Matrimonio, matrimonii. Milán: Giuffrè, 2000, p. 180. 
preocupa sobremanera a la Iglesia. ${ }^{12}$ El modelo, además, fue concebido, bajo una autoridad estricta del marido/padre, como un mecanismo para diluir o evitar los conflictos intrafamiliares y apuntalar la cohesión del grupo.

Dado que el matrimonio se traduce en la creación de lazos de orden legal entre la pareja que lo contrae y sus descendientes, ello aporta certeza no solo a los contrayentes, sino también a los terceros y al propio Estado vigilante. Todo aquello que pueda convulsionar la seguridad y estabilidad (y la ilusión que se quiera tener sobre ellas) debe ser rechazado, prohibido o, cuando menos, ignorado.

Se ha dicho, sobre el particular, que una de las fisuras que se advierte en la familia proviene del incremento de las uniones «ilegítimas» y de los hijos nacidos de parejas no casadas o de uniones esporádicas, así como de madres solteras. En respuesta, se postula un reforzamiento del modelo institucional como el único hábil para garantizar la supervivencia de la familia. En esta perspectiva, los defensores del matrimonio también son partidarios de reducir, cada vez más, el lugar que pueda ocupar el divorcio en el ordenamiento. Sin embargo, resulta incuestionable que una de las consecuencias de la liberación femenina y de los espacios ganados por las mujeres es la de optar, en no pocos casos, por tener descendencia sin haber formado previamente una familia, dado que no tienen incentivos para ser parte de un grupo, sino que, tan solo, aspiran a ser madres y, como es obvio, para ello no necesitan casarse o unirse en una relación de afectividad análoga a la conyugal.

Sabido es que una gran parte de quienes deciden no contraer nupcias rechaza la formalidad del matrimonio al querer vivir «sin papeles». Pero con ello, como bien se ha anotado, también rechazan el plano sustancial del matrimonio, pues huyen del estatus de cónyuge y del régimen que la ley dispensa a estos; de los derechos; y, sobre todo, de las obligaciones que les impone; en pocas palabras, no solo huyen de la ceremonia, sino del modelo institucional que elimina la elección de la libertad. ${ }^{13}$ Pese a querer mantener un amplio espacio para la adopción de decisiones relativas a la continuidad o terminación de la convivencia sin los efectos que implica, por el con-

12 Véase las interesantes apreciaciones de POSNER, Richard. Sex and reason. Cambridge: Harvard University Press, 1992, p. 243 y ss., quien sostiene que, entre otras cosas, a la Iglesia le interesa concebir al matrimonio como una forma de evitar las relaciones sexuales fuera de dicho contexto, incluso promoviendo su celebración a una corta edad ("but not too young», como dice Posner).

13 Como dice Astone, María. "Ancora sulla famiglia di fatto: evoluzione e prospettive». En Il Diritto di famiglia e delle persone. Fascículo 4. Milán: Giuffrè, 1999, p. 1477, la decisión de vivir en concubinato proviene "dalla non acettazione di un vincolo che, nella sostanza, si vuole non incida sul rapporto affettivo esistente tra essi partners, oppure, ancora, da una preferenza verso scelte privatizate, anziché istituzionalizzate». 
trario, la ruptura de un matrimonio, los concubinos demandan, cada vez con mayor vehemencia, protección legal a favor de sus uniones no conyugales. Es decir, huyen de la ley para luego recurrir a ella. ${ }^{14}$

Es necesario, no obstante, precisar de modo adecuado cuál es el sentido de sus reclamos, dado que, al privilegiar la autonomía privada para organizar su vida en común, así como la libertad para dar por concluida la unión de hecho y regular las consecuencias patrimoniales en caso de ruptura, lo que demandan es que se proteja legalmente ese particular modo de convivir - en el que, repito, reina la libertad antes que la sujeción a un régimen definido heterónomamente- y que se respete ese amplio margen de «maniobrabilidad» basado en los acuerdos privados entre los concubinos.

Ese juego entre el no al derecho (matrimonial) y el sí a un derecho ad hoc (especialmente concebido para las uniones libres: he allí el acento) ha sido denunciado como una forma de juridificar y de dar un trato equivalente e, incluso, más favorable que el trato otorgado a los matrimonios a lo que, curiosamente, brilla por ser precario, inestable, transitorio; de ese modo, se ampara una suerte de liberalismo en materia familiar que conduce, simultáneamente, a una desjuridización del matrimonio, al vaciamiento de su contenido y a la pérdida de su importancia, lo cual implica, para una autora como Palazzani, privatizar el matrimonio (reduciéndose el control sobre la institucionalidad familiar) ${ }^{15} \mathrm{y}$ "publificar» las uniones no conyugales pero siempre dentro de los amplios espacios de autonomía reclamados por los concubinos. ${ }^{16}$

14 Como dice PalAzZanI, Laura. "La famigilia «di fatto» è giustificabile giuridicamente?». En II Diritto di famiglia e delle persone. Fasc. 1. Milán: Giuffrè, 2000, p. 246: "La richiesta di legittimazione della famiglia di fatto manifesta l'intenzione di volere e non volere, al tempo stesso, il diritto: più precisamente, di volere che il diritto configuri e tuteli, sul piano pubblico, la scelta soggettiva che deve rimanere privata. Insomma, $i$ concubini vogliono che la loro scelta soggettiva e mutevole, analoga al rapporto ocasiónale, abbia un riconoscimento pubblico, analogo al matrimonio legale». Más adelante (p. 247), la misma autora señala que se trata de "l'attegiamento di ambivalenza tra antigiuridismo e giuridificazione, tra rebellione e intolleranza nei confronti del diritto, vissuto come soffocante, e richiesta di intervento flessibile, aperto e leggero del diritto, al quale si chiede di garantire la libertà della coscienza soggettiva. I concubini esaltano la scelta privata (sul piano morale): in un certo senso, chiedono l'asservimento della dimensione pubblica alla scelta privata, I'asservimento del diritto alla volontà e alla sua estrinsecazione (se non, addititura, amplificazione). In concreto, i concubini pretendono che il diritto li riconosca pubblicamente, distinguendoli dalle unione episodiche, ma al tempo stesso manteniendo la libertà sulla scelta del modo di vivere la relazione, di sciogliere il legame in qualsiasi momento, anzi tutelando la posibilita dello scioglimento, la revocabilità della decisione e regolando le conseguenze della scelta nella protezione dei soggetti convolti».

15 Igual posición asume NAVARRO-VAlLS, Rafael. Matrimonio y derecho. Madrid: Tecnos, 1995, pp. 67-68, para quien el proceso de reconocimiento de las uniones de hecho conduce a un proceso de contractualización del matrimonio.

16 Palazzani, Laura. Op. cit., p. 249. 
Además, se acusa la precariedad de la cohabitación que, según se dice, engendra con demasiada frecuencia familias monoparentales o el aumento del número de hijos de madres solteras que terminan siendo abandonadas. ${ }^{17}$

En suma, se rechaza el intento de toda regulación debido a que aceptarla implicaría consagrar un régimen en pro del «individualismo» familiar que se estrella contra los intereses de la familia matrimonial concebida como grupo "formalizado». Y, por ello, se señala que no se puede tutelar la libertad absoluta; además, la configuración pública (es decir, de normas obligatorias) de la convivencia more coniugali podría violar la autonomía que tanto reclaman los concubinos, con lo cual un régimen legal a favor de las parejas no casadas no solo termina causando estragos al matrimonio sino, también, a la propia unión libre. ${ }^{18}$

En esta misma perspectiva, se afirma que proteger a las uniones extramatrimoniales es dispensar tutela a lo variable, a la libertad cambiante, a la asociación ocasional y precaria de intereses, a la entrega corporal caracterizada por falta de compromiso. ${ }^{19}$ Tutelar las uniones de hecho significaría optar por una concepción del derecho que se pone al servicio de voluntades privadas en un terreno tan álgido como el de la familia. Por ende, solo se debe proteger al matrimonio, ${ }^{20}$ incluso más allá del pluralismo, pues una cosa son las opciones que derivan de este y que deben mantenerse en ese mundo de las diversidades y otra cosa son las instituciones que el ordenamiento debe acoger como propias del derecho de familia. ${ }^{21}$

Algunos juzgan que la apertura a otros tipos de familias produce una desvinculación entre los fines trascendentes del matrimonio y privilegia lo físico, lo sexual, el hedonismo. Por ello, es necesaria la consagración de la "contractualización" de áreas en las que la presencia de "lo público» no puede desaparecer, si es que no queremos arriesgarnos a promover desorden, caos, promiscuidad.

17 Véase NAVARRO-VAlls, Rafael. Op. cit., p. 84.

18 PALAZZANI, Laura. Op. cit., p. 251

19 Díaz Moreno, José M. ${ }^{a}$, S. J. "Las familias de hecho: aproximación a su vertiente éticocanónica». En Uniones de hecho. Una aproximación plural. Madrid: Publicaciones de la Universidad Pontificia de Comillas, 1999, p. 114, dice: "Creemos que es un error, equiparar el matrimonio con otro tipo de uniones que no llevan consigo el compromiso público y libremente asumido, de estabilidad permanente, y otras determinadas obligaciones, que derivan de ese compromiso». Pese a ello, para este religioso, la protección de tales uniones sí es necesaria, especialmente para atender los intereses de los hijos, que no eligieron nacer en un hogar no matrimonial.

20 Palazzanl, Laura. Op. cit., p. 253 y ss.

21 Díez-PICAZO, Luis. "Las nuevas fronteras y la crisis del concepto de familia». En Aída Kemelmajer de Carlucci (coord.). El derecho de familia y los nuevos paradigmas. T. I. Buenos Aires: Rubinzal Culzoni, 1999, pp. 26-27. 
En una posición más radical, pero no por ello menos importante, se sostiene que la simple unión de hecho no da lugar a relaciones jurídicas familiares, por lo que la relación que se establece en las parejas no casadas no puede encuadrarse en el modelo de familia que el ordenamiento protege, porque no hay vínculo jurídico, y, por tanto, no existe una situación organizada unitariamente dentro del orden jurídico total por un especial principio jurídico. ${ }^{22}$

En nuestro medio, un jurista de conocida formación conservadora como Cornejo Chávez considera que, en los países más industrializados, en los que el progreso científico, técnico y económico parece correr parejo con "cierta descomposición moral, típica por lo demás, de las épocas de decadencias de las culturas", el concubinato empieza a tener mayor significación, como una suerte de repudio al orden institucional o anhelo de una así entendida liberación. ${ }^{23} \mathrm{El}$ argumento, en síntesis, es más una apreciación de matiz moral antes que legal, como suele ocurrir con todos aquellos que se oponen radicalmente a acoger a la cohabitación no basada en el matrimonio.

Sin embargo, y para no faltar a la justicia, el propio Cornejo Chávez explica que las razones por las cuales se pone empeño en extirpar el concubinato no son únicamente de orden religioso, sino también de carácter sociológico, y que pueden resumirse en que la libertad sin límites de que gozan los concubinos es incompatible con las familias que crean. Al efecto, explica el Ponente del Libro de Familia del Código Civil que existen tres razones para ello: (a) desde el punto de vista de la mujer, generalmente el sujeto débil de la relación, el concubinato la coloca en el doble riesgo de quedar desamparada cuando ni los hijos que ha procreado, ni su edad, ni el propio antecedente de su convivencia le brindan la perspectiva de una unión duradera, y el de que además su conviviente la despoje del patrimonio que ella ayudó a formar con su trabajo o colaboración directa; (b) desde el punto de vista de los hijos, la inestabilidad de la unión concubinaria no es la mejor garantía para su manutención y educación; y (c) para los terceros que, engañados por la apariencia de un matrimonio, contratan con una presunta sociedad conyugal. ${ }^{24}$ Sin duda, se trata de argumentos interesantes, que no pueden ser ignorados; pero también se evidencia un marcado prejuicio que posiblemente marcó su posición al momento de sugerir el

22 González Moreno, Beatriz. "Uniones de hecho y derecho a la adopción». En J. M. Martinell y M. ${ }^{a}$ T. Areces Piño (eds.). Uniones de hecho, XI Jornades Jurídiques. Departament de Dret Privat, Facultat de Dret i Economia, Universitat di Lleida, 1998, p. 278.

23 CoRnejo Chávez, Héctor. Op. cit., p. 65.

$24 \quad$ Ib., pp. 67-68 
tratamiento jurídico que la ley civil terminó por «obsequiar» (que se me perdone el sarcasmo) a las situaciones convivenciales no matrimoniales.

\section{La crisis del modelo matrimonial como legitimador de la familia}

La familia, considerada como una institución natural, quizá como la única institución social que ha estado presente en todas las culturas y civilizaciones a pesar de que lo haya hecho de diversas formas, no ha escapado al influjo de los cambios sociales que presionan sobre su estructura o funciones, dado que no ha podido ser impenetrable o insensible a las transformaciones de su entorno. ${ }^{25}$

Como bien ha dicho Fukuyama, desde la década del sesenta, el Occidente ha experimentado una serie de movimientos de liberación que buscan despojar al individuo de las limitaciones impuestas por muchas de las tradicionales normas sociales y regulaciones morales vigentes. La revolución sexual, la liberación femenina, los movimientos feministas y, en las décadas del ochenta y noventa, los movimientos en favor de los derechos de los homosexuales y lesbianas han estallado en todo el mundo occidental. ${ }^{26}$

Las tradicionales funciones de la familia relacionadas con la educación, la integración de sus miembros al seno social, la cooperación entre los consortes, la colaboración entre ellos para la crianza de los hijos y la asistencia y solidaridad que se predicaba de aquella vienen sufriendo serios embates. Quizá uno de los datos más importantes de esta transformación, que pasa hoy en día desapercibido, por ser una vieja conquista (pero que se actualiza constantemente por el crecimiento de los índices de violencia familiar), sea el hecho de que la familia autoritaria, destinada a mantener una unidad intrafamiliar a todo costo (evitando los conflictos) y caracterizada por la imposición de las decisiones del marido y padre, ha sido sustituida por una familia «democrática», en la que las opiniones de todos los integrantes cuentan. Esta es una expresión incontrastable, en mi concepto, del caudal de derechos individuales provenientes de la legislación nacional y supranacional del siglo XX que dejó de lado el modelo de la familia "entelequia» y que la posa, por el contrario, como medio de realización de aspiraciones personales, individuales. ${ }^{27}$

25 HeRnÁNDEZ RODRÍGUeZ, Gerardo. "Análisis y perspectivas sociodemográficas de las uniones de hecho». En Uniones de hecho. Una aproximación plural. Op. cit., pp. 5 y 7.

26 FUKUYAMA, Francis. Op. cit., p. 32.

27 Bien ha dicho la socióloga española ALBERDI, Inés. "La nueva familia democrática». En Temas para el Debate. Madrid, 38, 1998, pp. 38 y ss., especialmente p. 40, que, en las 
En las sociedades posindustrailes, se asiste a una desvalorización de la familia. Ya no es más una unidad de producción sino de consumo ${ }^{28}$ y, como bien dice el reconocido jurista argentino Ricardo Lorenzetti, en los tiempos actuales, cada miembro de la familia trabaja en una empresa distinta o es desocupado, y tienen horarios, ingresos, expectativas de crecimiento y demandas externas disímiles, lo que hace que la organización del tiempo y de los recursos familiares se fragmenten según las necesidades del individuo y no del grupo; de esta forma, desaparece la unidad. ${ }^{29}$ Como se ha dicho con razón, la familia de clase media con una sola fuente de ingresos se ha extinguido. ${ }^{30}$

La función educadora es sustituida paulatinamente con la educación escolar y universitaria $;{ }^{31}$ los cuidados de los hijos fuera de la escuela se encomiendan a terceros, dado que los padres son trabajadores que salen al mercado laboral casi toda la jornada; ${ }^{32} \mathrm{y}$, en muchos casos, los intereses personales de los esposos suponen una postergación de la decisión de tener descendencia, lo que incide en las tasas de fertilidad. El cuidado de los ancianos y el cuidado de la salud son trasladados a la seguridad social, ${ }^{33}$ ya que esta puede ser más eficiente; ${ }^{34}$ así, se excluye a los ancianos del grupo familiar que habita bajo el mismo techo para ser llevados a casas de retiro o de cuidados especiales.

relaciones entre iguales, se producen conflictos más fácilmente y hay que negociar y entenderse para solucionarlos. No es posible imponer la voluntad y la autoridad de una de las partes. Además, continúa la autora, la libertad mantiene las posibilidades de todos los medios para tomar otra alternativa: marcharse. Líneas después (p. 41), Alberdi sostiene que, en la sociedad española de fines del siglo Xx, el individuo aparece como la base de la definición del bienestar y solo es en función de la libertad y del bienestar individual que van a tomarse medidas de apoyo de la familia. Sin duda, se refiere al actual y preocupante conflicto entre individuo y familia advirtiendo, como también lo ha hecho el jursita argentino Ricardo Lorenzetti en un extraordinario ensayo, "Teoría general del derecho de familia: el conflicto entre los incentivos individuales y grupales». Actualidad Jurídica, t. 87, febrero, 2001, p. 43 y ss., Lima, que es un trabajo de ineludible lectura. FUKUYAMA, Francis. Op. cit., p. 62.

29 LORENZETTI, Ricardo. Op. cit., p.45.

30 TUBERT, Silvia. "Introducción al volumen dedicado a Familias y parejas: paradojas y nuevas opciones». Revista de Occidente, n. ${ }^{\circ}$ 199, diciembre, 1997, p. 6, Madrid.

31 FuKUYAMA, Francis. Op. cit., p. 62.

32 VEGA MERE, Yuri. «La familia por venir: entre lo público y lo privado; entre la tradición y la modernidad (o lo disparatado)». Revista Jurídica del Perú, junio, 2002, pp. 78-79, Trujillo.

33 LORENZETTI, Ricardo. Op. cit., p. 45.

34 BECKER, Gary S. A Treatise on the Family. Edición aumentada. Cambridge: Harvard University Press, 1993, p. 349. 
Por otro lado, la revolución sexual, la ocupación laboral de la mujer y los movimientos feministas han mutado radicalmente el rol de la mujer. Gracias a los métodos de control de la natalidad y al análisis económico del descenso de las tasas de fertilidad, que han puesto en evidencia que el hecho de tener hijos supone altos costos (transferencia de recursos de los padres a los hijos), ${ }^{35}$ que en la actualidad son más altos por las exigencias propias de la sociedad de la información y de la competencia, la mujer de hoy privilegia, en el tiempo, su realización personal y profesional (al igual que el esposo) y posterga, como antes se anotaba, la procreación. ${ }^{36}$

La familia nuclear, compuesta, en oposición a la familia extensa, por consortes e hijos, sigue diluyéndose, no solo como consecuencia de la mayor independencia económica de la mujer, que en en muchos casos le permite adoptar la decisión de tener descendencia sin necesidad de casarse o de convivir (incluso mediante el recurso a técnicas de reproducción humana asistidas), sino también por el hecho de que la tasa de nacimientos ha caído dramáticamente en las sociedades posindustriales, y en las clases de mayores recursos o en la clase media de los países en vías de desarrollo. Al mismo tiempo, se observa un crecimiento de hogares unipersonales que no son familia: personas que prefieren dedicarse a sus propios asuntos sin querer asumir responsabilidades y los costos derivados de una unión convivencial o de tener hijos; de ese modo, se relaja los lazos sociales basados, en buena parte, en los vínculos de parentesco. Las familias sin hijos o los hogares unipersonales apuestan menos por el grupo que por ellos mismos.

Tubert considera que uno de los aspectos más relevantes que incidió en la transformación de la familia es la crisis del matrimonio, que se manifiesta en la decadencia de su contenido institucional (registro de las uniones) y ritual (ritos sociales, religiosos y civiles que las acompañan). Según la autora, el número de uniones legales disminuye en razón de las relaciones prácticas y simbólicas que los individuos mantienen con la institución familiar, al tiempo que se debilita el carácter sagrado de las formas más ritualizadas del matrimonio. Ello responde, afirma Tubert, a los cambios económicos, demográficos y sociales. Para la misma autora, desde un punto de vista ideológico, el avance del matrimonio por amor llega al punto de liquidar al matrimonio mismo, por cuanto opone la exigencia de sinceridad del compromiso interpersonal al formalismo de las convenciones. ${ }^{37}$

Continúa diciendo Tubert que una de las mayores evoluciones de los últimos años es el cambio de actitud de las mujeres con respecto a las formas de

\footnotetext{
35 Ampliamente, ib., pp. 135 y ss.

36 Ib., p. 352.

37 TUBERT, Silvia. Op. cit., p. 7.
} 
establecerse socialmente: el matrimonio ya no es la forma principal de establecimiento social para ellas, como lo era hace treinta años. Ahora aspiran a preservar su autonomía en la orientación de su trayectoria vital y profesional. Existe rechazo al matrimonio debido a que de este se deriva la división tradicional de los roles sexuales y porque, según afirma, en expresión que resulta de elevado interés, "la adopción de la vida en pareja no tiene un carácter fusional sino que pretende ser asociativa y reversible». ${ }^{38}$

La erosión del modelo tradicional de familia basada en el matrimonio también tiene relación con los afectos. Bien dice Julio Iglesias de Ussel que los elementos considerados esenciales de la vida familiar de hoy son históricamente muy recientes, tienen un pasado muy corto: la elección de la pareja por los propios contrayentes, la selección fundada en el amor, la legitimación social para la ruptura en caso de desaparición de los afectos de la pareja, etc. ${ }^{39}$ ¿Es posible encontrar esos amplios espacios de elección hoy en día sin necesidad de recurrir al matrimonio si en el pasado este prescindió, con frecuencia, de la opinión y los sentimientos de la pareja al concertarse las nupcias por terceros y no por los propios interesados?

En el escenario actual de la familia, se advierte el reconocimiento y reivindicación del pluralismo. Como dice Iglesias de Ussel, se ha pasado de una configuración monolítica de la familia a otra pluralista, en la que las distintas modalidades de articular la vida familiar — cohabitación o matrimonio, hijos dentro o fuera del matrimonio, familias biparentales o monoparentales, uniones heterosexuales u homosexuales - reclaman legimitidad social y, en ocasiones, regulacion legal. Como anota este autor: «El reconocimiento del pluralismo supone la ruptura con el anterior tipo único de familia, con una fuerte protección legal y - en parte- social, que situaba cualquier otra modalidad de convivencia fuera de la legalidad cuando no condenada penalmente». ${ }^{40}$ Este pluralismo ha alimentado la imagen de crisis del modelo único. ${ }^{41}$

Al lado del pluralismo, es claramente perceptible que el profundo cambio en el modelo familiar único es sistentizado por algunos en la fórmula la familia para el individuo y no, como ocurría en el pasado, el individuo para la familia. ${ }^{42}$ Esta fórmula muestra la diferencia entre la familia-institución (el matrimonio), que se considerada como un valor en sí mismo, portadora

38 Ib., pp. 7-8.

39 IGLESIAS DE USSEL, Julio. "Crisis y vitalidad de la familia». En Familias y parejas: paradojas y nuevas opciones. Revista de Occidente, n. ${ }^{\circ} 199$, diciembre, 1997, p. 22, Madrid.

$40 \quad$ Ib., p. 29.

41 Ib., p. 30.

42 BILE, F. "La famiglia di fatto: profili patrimoniali». En La famiglia di fatto. Atti del Convegno Nazionale di Pontremoli. Montereggio, 1977, p. 71. 
de intereses colectivos que subordinan los individuales, y la «nueva» familia, que emerge de una nueva visión de esta como lugar privilegiado de afirmación y realización de la personalidad de los individuos, ${ }^{43}$ como espacio de afectos de sus miembros, reservado a satisfacer las necesidades de seguridad existencial y de relaciones sociales y emocionales, que se signa como un proceso de progresiva interiorización o privatización del grupo ${ }^{44}$

Este «individualismo» familiar (sin tener connotación peyorativa) se ve respaldado, haciendo mías las expresiones de Lorenzetti, por la explosión de los intereses invididuales dentro del grupo familiar. ${ }^{45}$

La tendencia hacia la afirmación del individualismo en las relaciones familiares viene confirmada, como dice Del Dotto, en la realidad social por una serie de factores: aumento de divorcios, reducción de la natalidad, reducción de la tasa de nupcialidad y el surgimiento paralelo de una multiplicidad de realidades familiares alternativas respecto de aquella conyugal, en la que tienen singular relevancia las uniones de hecho como una evidente manifestación de las cada vez más difundidas exigencias de libertad y autonomía individual. Como dice la autora, el incremento de la convivencia more uxorio y las nuevas orientaciones sobre ella inciden, incluso, sobre una mayor demanda de flexibilización del matrimonio ${ }^{46}$ (que los opositores a su admisibilidad consideran, según vimos, como una desjuridización de las nupcias). ${ }^{47}$

43 Astone, María. Op. cit., p. 1463

44 DotTo, Brunilla del. "Sui rapporti patrimoniali tra conviventi more uxorio». En II Diritto di famiglia e delle persone. Fascículos. 2-3. Milán: Giuffrè, 1999, p. 876.

45 LORENZETTI, Ricardo. Op. cit., p. 45.

46 DotTo, Brunilla del. Op. cit., p. 879. A estas alturas, creo que es del todo conveniente coincidir con FERRANDO, Gilda. "Convivenze e modelli di disciplina». En Francesca Brunetta d'Usseaux y Antonino d'Angelo (eds.). Matrimonio, matrimonii. Milán: Giuffrè, 2000, p. 302, y con gran parte de la doctrina italiana que ha abordado el tema de las uniones de hecho, cuando, contrariamente a lo que entienden los defensores a ultranza del modelo conyugal, tradicionalmente entendido como el único válido, afirma que la llamada "desjuridización» o "privatización» del matrimonio debe ser entendida como un proceso que implica mayor autonomía al interior de la unión conyugal, mayores espacios para las decisiones de los propios interesados en lugar de definiciones heterónomas supuestamente más justas.

47 Me parecen fundamentales las apreciaciones efectuadas en notable síntesis por VITA, Ana de. "Note per una comparazione». En Bruneta d'Usseaux y Antonino d'Angelo (eds.). Matrimonio, matrimonii. Milán: Giuffrè, 2000, pp. 143-175, especialmente p. 167, cuando señala que la "privatización» de la familia ha salvado el modelo (matrimonial), aunque destruya su unidad. En efecto, creo convencidamente que el rechazo a la rigidez institucional y el hecho de abrirle las puertas a la unión libre ha tenido como uno de los más importantes efectos (que suelen pasar por alto quienes ven el tema con malos ojos) el generar un favorable y conveniente clima de distensión en materia familiar que podría haber llegado a extremos impensables en desmedro de la institución matrimonial. 
Las uniones de hecho, gracias al pluralismo en materia familiar, no son miradas con recelo, reprobación moral y jurídica, especialmente en el mundo occidental. ${ }^{48}$ Existe una consideración más positiva del fenómeno, mayor tolerancia, más aceptación. Finalmente, se trata de una realidad ineludible, inocultable.

Además, las formas familiares que han surgido como alternativa al modelo único muestran que

la familia se amolda a los intereses individuales al mismo tiempo que se desacomoda respecto de los parámetros que la sociedad ha establecido como típicos. Los individuos se «juntan» de distintas maneras según encuentren su satisfacción, y ello resulta «herético» en términos de la vida matrimonial típica pensada como base de la organización social. ${ }^{49}$

Como bien ha dicho Lorenzetti, la unión matrimonial sexual y la reproducción han dejado de ser el único modelo; ${ }^{50}$ surge, en palabras del lúcido autor, una «atipicidad» que viene dada por las múltiples relaciones que no se ajustan al modelo, como ocurre, por ejemplo, con las uniones de hecho, que incide en el concepto mismo de familia. ${ }^{51}$

Pese a la consagración de un modelo familiar único y excluyente, el concubinato nunca desapareció como realidad fáctica. Además, aunque se trate de argumentos frecuentemente expuestos por los colectivos de gays y lesbianas o por quienes convienen en reconocer demandas de orden familiar a favor de estos colectivos, el matrimonio no fue siempre el prototipo de unión verdaderamente libre. En la Europa del medioevo y de las monarquías fue un medio de alianzas para conservar el poder de los gobernantes (y distribuirse geográficamente el continente y las colonias) y, fuera de las relaciones de poder, las nupcias eran utilizadas como instrumento de consolidación de patrimonios sin importar los afectos de los contrayentes. La idea del amor como justificación aparece recién en el siglo XVIII, pero ello no desechó seguir recurriendo a la institución como una forma de crecimiento de las riquezas familiares, ${ }^{52}$ cuestión que, como es claro, no aplicaría a los descastados, al proletariado, diría Karl Marx. Asistimos, quiérase o no, a una etapa en la que se redimensionan los afectos — la affectio maritalescomo fundamento de la vida en común, exista o no vínculo conyugal.

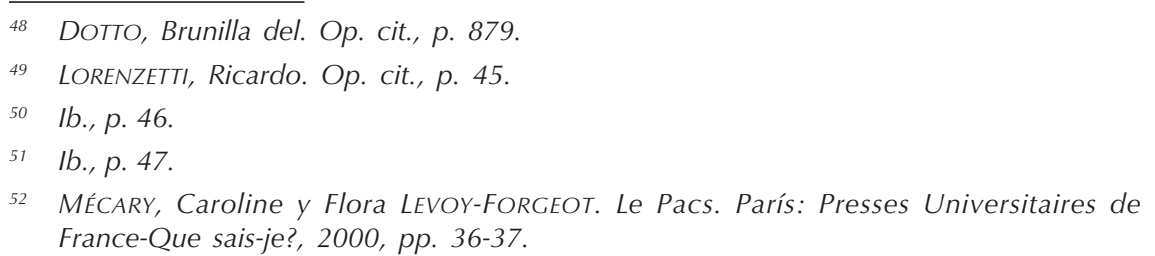


La pretensión de querer englobar los sentimientos y las opciones raigalmente personales a los dogmas volcados en las normas no resiste el paso de los siglos ni es capaz de contener las mutaciones que se revelan en el plano sustancial, en la dimensión sociológica y en las convicciones colectivas. En un siglo recargado de demandas de libertad, como lo fue el siglo XX; en una fase histórica como la que hemos vivenciado en la última centuria, en la que se ha acentuado la vertiente individual de los sujetos y en la que el Estado y los organismos internacionales sancionaron instrumentos universales que se convirtieron en títulos de justificación o de plasmación de nuevos derechos y de mayores espacios de autonomía; en un inocultable período de transición, que va de una sociedad que pretendió ser sometida a la consabida homogeneidad a una sociedad en la que se reconoce la diversidad, la necesidad de rescatar y respetar las culturas y los valores locales y regionales (el multiculturalismo); en un tiempo en que la posmodernidad implica las diferencias de opciones, de cosmovisión, de elección, de rechazo a la «uniformidad» con la que quiso arrasar las invencibles divergencias; etc., resulta cuestionable seguir afirmando la existencia de un modelo familiar único e ignorar los cambios que la experiencia ha puesto ante nuestra mirada.

\section{Necesidad de juridificar las situaciones convivenciales}

En cualquier caso, creo que, como fenómeno social, las uniones de hecho, hoy en día, tan igual como ocurre con el matrimonio, crean situaciones familiares ${ }^{53}$ que deben ser atendidas por el derecho. Nadie duda de que las relaciones con los hijos nacidos de la convivencia no conyugal se encuentran plenamente «juridificadas», pero el tema que concita mayor preocupación es el de la regulación de las relaciones, derechos y obligaciones de los convivientes entre sí, cuando no la protección que se debe a los terceros que, confiando en la apariencia matrimonial, entablan algún tipo de vinculación jurídica con los concubinos sin que la ley les provea de soluciones adecuadas. Quizá este sea uno de los puntos más problemáticos en los sistemas legales que carecen de todo tipo de pronunciamiento o que, aun teniéndolo, no se han sumado a la euforia de los países escandinavos (que se repite en la experiencia francesa) de querer registrar las uniones convivenciales con el propósito de darles certeza, no solo para protección de los propios convivientes sino también de los terceros.

53 SILVEIRA RAMOS, Carmen Lucía. Op. cit., p. 40 señala que la «familia sem casamento» es una situación de hecho que envuelve una realidad socioafectiva que aflora espontáneamente en el mundo real, engendrando relaciones de tipo familiar. Para esta autora, la familia informal, como formación sociojurídica, existe en función de la realización de exigencias humanas e implica un espacio de solidaridad y colaboración mutuas tanto en el plano afectivo como en el material, incluido el patrimonial. 
A lo apenas dicho, creo que debe sumarse que las uniones de hecho han mostrado ser, como lo dice la frondosa legislación autonómica española sobre parejas estables, situaciones convivenciales de afectividad análoga al matrimonio, comunidades de vida, de metas, de proyectos, de asistencia y socorro mutuos, aun sin imposición de dicho deber ope legis. Muchas familias tienen su origen en un concubinato y sus miembros invierten en ellas sin importarles la existencia de un lazo de orden legal para asumir voluntariamente una serie de deberes, incluso de solidaridad, de fidelidad y entrega recíprocas; en suma, estamos ante comunidades de afecto en las que todo se comparte: los ingresos, los afectos, el esfuerzo, la crianza de los hijos, la adquisición de los bienes materiales instrumentales que permiten una vida digna, etc.

A ello se añade que el desconocimiento legal de las uniones libres puede favorecer la irresponsabilidad paterna o bien contribuir a someter a los más débiles, particularmente en el régimen económico y en las relaciones personales cuando hay maltrato y violencia intrafamiliar. Por ello, no cabe el silencio legislativo para desconocer uniones que se sustentan en principios de solidaridad, igualdad, unidad, justicia y equidad. ${ }^{54}$

Por supuesto, no podemos pasar por alto la mayor duda mostrada por todos los que han abordado el tema: el no querer traicionar la elección libre de los concubinos que han querido evitar no solo la formalidad sino también el estatuto que la ley contempla para el matrimonio. Esta duda, al ser absuelta, implicará una toma de posición respecto de qué régimen aplicar al concubinato, si es esa la necesidad que se discute, ya sea en caso de vacío legal o cuando las normas que se refieren a aquel resultan insuficientes.

Algunos son partidarios de dejar todo a la autonomía privada, sin que ello signifique abandonar al conviviente débil al arbitrio del más fuerte. En tal perspectiva, se afirma como necesario tener confianza y, al mismo tiempo, revalorizar la autorresponsabilidad de cada cual, es decir, tomar conciencia en el sentido de asumir un nuevo tipo de temperamento ante las relaciones de convivencia que vea en la libertad de elección de vivir como pareja una manifestación y reivindicación de una ansiada (y obtenida con sumo esfuerzo) igualdad de sexos. Por ello, se alega la ilegitimidad de una aplicación por vía analógica de la normativa matrimonial. Para quienes profesan esta solución, «la autonomía privada se presenta como el único instrumento jurídico capaz de garantizar una tutela más eficaz e incisiva, de carácter preventivo, al conviviente more uxorio, en un momento en el cual en el campo del derecho de familia se asiste al resurgimiento del instrumento

Según concluye PItTí, Ulises. "Las uniones de hecho (Sus nuevos paradigmas)». En Aída Kemelmajer de Carlucci (coord.). El derecho de familia y los nuevos paradigmas. T. III. Buenos Aires: Rubinzal Culzoni, 2000, p. 210. 
negocial». ${ }^{55}$ Debe quedar claro, en cualquier caso, que en esta posición lo que se discute es la reglamentación de los intereses patrimoniales entre concubinos.

Otros dudan sobre si, ante cualquier posible invasión que cercene la libertad de elección de la pareja estable, no sea mejor mantener la protección recurriendo a las tradicionales figuras que pertenecen al derecho de las obligaciones u otras ramas, sobre todo para tutelar intereses de orden patrimonial. ${ }^{56}$ Aun así, aquellos que evidencian su hesitación y que no descartan la aplicación de estos remedios no dejan de reconocer que las exigencias que son satisfechas por las uniones de hecho paraconyugales, incluso similares a las que se colman por medio de las instituciones familiares tradicionales, se colocan, en realidad, en otro plano, igualmente digno de respeto y de garantía contra el abuso, la mala fe, el maltrato. Y es en el plano de la tutela de la persona en cuanto tal en el que el sistema debe asegurar su desarrollo y las condiciones de igualdad económica y social. Es el plano en el que debe primar el valor de la solidaridad, como ha ocurrido con la legislación previsional, social y laboral que en no pocos países integran a los convivientes a los beneficios otrora reservados únicamente a los cónyuges. Lo mismo ocurre con algunas figuras civiles (sucesión en la locación, resarcimiento de daños, etc.), que demuestran que lo que está en juego es el reconocimiento de derechos o intereses fundamentales para la persona. ${ }^{57}$

A diferencia de Del Dotto, que libra a la autonomía privada las decisiones sobre los intereses patrimoniaes, De Vita, como es claro, parece poner mayor acento en los aspectos personales o en los derechos personales que la ley debería reconocer a los concubinos. Quizá resulte conveniente integrar, en cualquier intento de regular situaciones convivenciales no matrimoniales, ambos planos, el personal y el patrimonial, sobre todo teniendo cuenta que la libertad de elección para vivir fuera del estatuto matrimonial que se reconoce a los concubinos no debe estar privada de cierto control en caso de ejercicio abusivo de dicha libertad, ${ }^{58}$ especialmente al momento de la terminación de la unión de hecho.

Como bien se ha señalado, una eventual intervención legislativa no podrá tener, sin más, carácter sectorial y permisivo; por el contrario, debe apuntar a garantizar adecuadamente, en el ámbito de las diversas relaciones (entre los convivientes, entre estos y el ordenamiento y entre los concubinos y terceros), la actuación de intereses y valores considerados imprescindibles

55 DOtTo, Brunilla del. Op. cit., p. 882.

56 VITA, Ana de. Op. cit., p. 172.

57 VITA, Ana de. Op. cit., pp. 172-173.

58 FERRANDO, Gilda. Op. cit., p. 314. 
en el actual ordenamiento de las relaciones familiares, tal como resulta también del nuevo derecho de familia: la realización de principios de igualdad y de paridad entre los convivientes bajo el perfil personal, económico y patrimonial, cuando no en el cumplimiento de los deberes inderogables de solidaridad humana y social previstos para el desarrollo y la promoción de la persona. ${ }^{59}$

Quiero hacer mías las apreciaciones agudas y acertadas del jurista uruguayo Gustavo Ordoqui cuando señala:

En la tendencia a equiparar consecuencias jurídicas, que es la que se advierte en nuestro medio, [se refiere a la realidad, doctrina y jurisprudencia orientales] no se desprestigia la institución familiar, sino que, por el contrario, se consolida en la medida en que las consecuencias jurídicas vendrán marcadas por la realidad de la vida y no por el cumplimiento de las formas.

Todos los que conviven de determinada forma deben o deberían asumir las mismas responsabilidades. Éste es el aspecto medular de nuestro tema.

Las soluciones vienen por el lado de la «asimilaciónx y no por el enfrentamiento.

Lo grave sería habilitar la vía de la irresponsabilidad, permitiendo que quienes mantienen una relación more uxorio lo puedan hacer sin asumir responsabilidades, tanto respecto de su pareja como de sus hijos.

En realidad, el Derecho no puede obligar a vivir juntos a tal persona con tal otra, sino que lo que que puede hacer es regular las consecuencias de sus actos cuando en los hechos se constituyó una familia. ${ }^{60}$

No se requiere mayor y mejor argumentación.

\section{Requisitos de la unión de hecho}

Creo que es importante definir a qué unión de hecho nos estamos refiriendo, pues, como ha sido señalado por diversos autores, existen variadas formas de convivencia. ${ }^{61}$

Para ello, resulta ineludible referirnos a nuestro marco constitucional y legal, pues el ordenamiento peruano contiene una delimitación interesante. Así, el artículo 5 de la Constitución de 1993 establece: «La unión estable de

59 AstOne, María. Op. cit., p. 1479.

60 ORDOQUI, Gustavo. "Matrimonio de hecho en la jurisprudencia uruguaya». En Aída Kemelmajer de Carlucci (coord.). El derecho de familia y los nuevos paradigmas. T. III. Op. cit., p. 159

61 Así, DotTo, Brunilla del. Op. cit., p. 880; González Moreno, Beatriz. Op. cit., p. 273; BORGONOVO, Oscar. El concubinato en la legislación y en la jurisprudencia. Buenos Aires: Hammurabi, 1987, pp. 25, 27, 37 y 47. 
un varón y una mujer, libres de impedimento matrimonial, que forman un hogar de hecho, da lugar a una comunidad de bienes sujeta al régimen de la sociedad de gananciales en cuanto sea aplicable».

Por su parte, el artículo 326 del Código Civil reza:

La unión de hecho, voluntariamente realizada y mantenida por un varón y una mujer, libres de impedimento matrimonial, para alcanzar finalidades y cumplir deberes semejantes a los del matrimonio, origina una sociedad de bienes que se sujeta al régimen de la sociedad de gananciales, en cuanto le fuere aplicable, siempre que dicha unión haya durado por lo menos dos años continuos.

La posesión constante de estado a partir de fecha aproximada puede probarse con cualquiera de los medios admitidos por la ley procesal, siempre que exista un principio de prueba escrita.

La unión de hecho termina por muerte, ausencia, mutuo acuerdo o decisión unilateral. En este último caso, el juez puede conceder, a elección del abandonado, una cantidad de dinero por concepto de indemnización o una pensión de alimentos, además de los derechos que le correspondan de conformidad con el régimen de la sociedad de gananciales.

Tratándose de una unión de hecho que no reúna las condiciones señaladas en este artículo, el interesado tiene expedita, en su caso, la acción de enriquecimiento indebido.

Ambas normas son de enorme gravitación. De ellas se desprende, en primer término, que:

a) La unión debe ser voluntaria, es decir, debe surgir de la espontaneidad, conocimiento y libre albedrío de las partes (affectio maritalis). ${ }^{62}$

b) Además, debe ser una unión entre un hombre y una mujer, es decir, debe tratarse de una unión heterosexual; de esta forma, quedan descartadas las parejas homosexuales. ${ }^{63}$

c) Cuando ambas normas se refieren a «un» varón y a «una» mujer aluden a la exigencia de la singularidad, de la exclusividad o monogamia, que se traduce en el deber de fidelidad entre los convivientes, que muchos se

62 Mangione Muro, Mirta H. Concubinato. Rosario: FAS, 1999, p. 19.

63 BIGIO CHREM, Jack. "El concubinato en el Código civil de 1984». En Libro Homenaje a Carlos Rodríguez Pastor. Lima: Cultural Cuzco, 1992; Alves MARTINS, Flavio. O casamento e outras formas de constituçâo da familia. Río de Janeiro: Lumen Juris, 2001, p. 151; Mangione Muro, Mirta H. Op. cit., p. 19; MARTINIC y WeINSTEIN. "Nuevas tendencias de las uniones conyugales de hecho». En Aída Kemelmajer de Carlucci (coord.). El derecho de familia y los nuevos paradigmas. T. III. Op. cit., p. 113; RUBIO CORREA, Marcial. Estudio de la Constitución Política de 1993. Lima: Pontificia Universidad Católica del Perú, 1999, p. 54 (refiriéndose a la Constitución); VEGA MERE, Yuri. "La eclosión de las legislaciones protectivas de las uniones homosexuales». Op. cit., pp. 259-261. 
niegan a concebir para los concubinos bajo la excusa (o denuncia) de que se trata de uniones libres. ${ }^{64}$

d) Cuando se hace referencia a la estabilidad o permanencia, se entiende que la pareja debe tener una comunidad de vida estable y duradera. ${ }^{65}$ En el caso de la ley peruana, es claro que se exige un plazo mínimo de dos años. Pero debe tratarse de un lapso de dos años ininterrumpidos; la unión no puede ser sostenida — se ha dicho- de forma interrumpida, ni los dos años pueden ser producto de la acumulación de períodos discontinuos. ${ }^{66}$

e) La estabilidad implica, de suyo, compartir un techo común y, además, cohabitar, ${ }^{67}$ es decir, vivir maritalmente como pareja, tener vida sexual. Como dice Beatriz González, debe haber «existencia efectiva de relación sexual», y añade luego que, dado que estas uniones constituyen una relación de afectividad análoga a la conyugal, cuando no hay hogar común, no hay concubinato. Así, quedan excluidas, por la ausencia de dicho requisito, las uniones esporádicas o circunstanciales, las homosexuales, las de los transexuales, las adulterinas, las de los mal llamados matrimonios a prueba, etc. ${ }^{68}$ Siguen la misma suerte aquellas situaciones en las que no se comparte una vida en común y solo se comparte el lecho los fines de semana o de modo infrecuente. Así lo ha resuelto, además, la Corte Suprema, mediante sentencia del 30 de enero de 1998, al señalar que hay concubinato cuando un varón y una mujer hagan vida de casados sin ser tales, siempre que exista carácter de permanencia o habitualidad, aunque calla sobre otros requisitos. Por ello, consideró que, en el caso materia de casación en el que se discutía la atribución de paternidad al demandado, no bastó que la demandada y el emplazado

64 MARTINIC y WEINSTEIN. Op. cit., pp. 116-117 se preguntan qué ocurriría con dos cónyuges que se encuentran separados de hecho y que, simultáneamente, cada uno por su lado, mantienen una unión estable, duradera, monogámica, con una persona distinta. Para estas autoras chilenas, tal hecho debe ser reconocido por el derecho y debe considerarse que el requisito de la monogamia (como patrón de la cultura judeocristiana occidental) debe entenderse satisfecho.

65 AlaGnA, Sergio. "Famiglia di fatto e famiglia di diritto a confronto: spunti in tema di rapporti bancari». En II Diritto di famiglia e delle persone. Fascículo. 1. Milán: Giuffrè, 2001, p. 287; LÓPEZ HERRERA, Francisco. Estudios sobre derecho de familia. Caracas: Universidad Católica Andrés Bello, 1998, p. 107 y ss.; PITTí, Ulises. Op. cit., p. 207.

66 BIGIO CHREM, Jack. Op. cit., pp. 155-156.

67 Así, Mangione Muro, Mirta H. Op. cit., p. 20. Para MartiniC y Weinstein. Op. cit., pp. 114-115, basta con que cohabiten, aunque no vivan bajo el mismo techo, criterio que no compartimos, pues una situación de ese tipo no implica una verdadera comunidad de vida.

68 González Moreno, Beatriz. Op. cit., p. 273. 
sostuvieran relaciones sexuales en forma esporádica en dos hoteles y que luego optaran por convivir cuando la actora resultó embarazada. Igual sentido tuvo la sentencia de la misma Corte, de fecha 19 de mayo de 1994, en la cual se señaló que, en todo caso, el concubinato en la época de la concepción es uno de los supuestos para establecer la filiación extramatrimonial, de acuerdo con el inciso 3 del artículo 402 del Código Civil. En este fallo, a diferencia de la sentencia citada, se hace referencia al requisito de la notoriedad, al igual que en la sentencia de la misma Corte, del 22 de julio de 1996, en la que se alude a los requisitos de permanencia, notoriedad y singularidad.

f) Los miembros de la pareja, además, deben encontrarse libres de impedimento matrimonial. Le asiste razón a Bigio cuando señala que, en este sentido, no basta con que no sean casados, pues este autor entiende que resultan aplicables los artículos 241 y 242 del Código Civil que regulan los impedimentos absolutos y relativos, respectivamente, para contraer matrimonio. ${ }^{69}$

Por cierto, el que uno de los concubinos hubiera procreado hijos en una relación distinta a la concubinaria no implica que tenga impedimento matrimonial, como lo ha resuelto la Corte Suprema mediante fallo del 9 de octubre de 1996, en el que una tercera pretendió demostrar que el concubino se encontraba incurso en tal impedimento por haber exhibido una partida de nacimiento en la que el conviviente - que había fallecido- figuraba como el padre de una menor.

g) La convivencia, sin embargo, no se «realiza y mantiene» (en palabras poco técnicas del Código Civil) para tener sexo, compartir techo y nada más. Es indispensable que la unión cumpla deberes semejantes a los del matrimonio, lo cual «implica que el comportamiento de la pareja deberá ceñirse a las pautas generales que el Código Civil señala respecto de las relaciones personales entre los cónyuges». ${ }^{70}$

h) Debe ser una unión notoria, pública, cognoscible por los terceros, de allí que la propia norma civil haga referencia a la "posesión de estado". No debe ser oculta, clandestina, pues ello podría denotar que la situación de los convivientes podría encontrarse al margen de tales exigencias.

i) Es evidente que las uniones libres, por ser tales, carecen de las formalidades que se requieren para la celebración del matrimonio. Los concubinos asumen una relación de manera voluntaria y así la sostienen, sin

69 BIGIO CHREM, Jack. Op. cit., p. 155.

70 Ib., p. 155. 
recurrir a autoridad alguna, especialmente en nuestro medio, en el que, a diferencia de las legislaciones escandinavas o de las que se inspiran en ellas (como Francia, Alemania y algunas autonómicas de España), no existen registros para las convivencia more coniugali.

No es requisito el que la pareja tenga hijos, aunque sea un indicio de convivencia o de relaciones maritales.

Pese a todo, aun cuando la convivencia presente los caracteres antes indicados, ella no genera estado civil distinto al que tengan los concubinos.

Cuando no se cumple con los requisitos antes señalados, se acostumbra a señalar que nos encontramos ante un concubinato «impropio», aunque no falta quien, con agudeza, señale que también podría considerarse como "forzosa» la convivencia en la que uno o los dos miembros tienen ligamen nupcial anterior del cual no pueden desprenderse ${ }^{71}$ muchas veces por razones ajenas a su propia intención.

El cumplimiento de tales exigencias, por lo demás, pese a la exigua regulación que tiene la unión de hecho en nuestro medio, resulta de particular interés (de la lectura del texto se desprende que la ley exige estabilidad por dos años, singularidad o exclusividad, notoriedad, comunidad de techo y de lecho, cumplimiento de fines similares al matrimonio, heterosexualidad y ausencia de impedimentos; asimismo, se da por entendido que se trata de uniones que carecen de formalidad), ${ }^{72}$ pues la no observancia de alguno o algunos de ellos tendrá notables diferencias en cuanto a los efectos que la norma reconocerá a los llamados concubinatos impropios o imperfectos.

Es cierto, por otro lado, que el Código no castiga de manera directa al concubinato adulterino en el sentido de asignarle efectos perjudiciales a la relación convivencial en sí misma, pero podría servir de justificación para el cónyuge a fin de poder demandar la disolución del matrimonio por causal, con las consecuencias que la ley prevé en contra del comúnmente calificado como cónyuge culpable dentro de las normas del divorcio-sanción que coexisten con la reciente modificación que introduce el divorcio por el cese efectivo de la convivencia y siempre que no se hubiere cumplido el plazo de caducidad establecido por el artículo 339 del Código Civil para fundar la acción en el adulterio.

BORGONOVO, Oscar. Op. cit., p. 37

72 También se refiere a los requisitos de comunidad de techo y lecho, singularidad, permanencia y ausencia de impedimentos PLÁCIDO, Alex. Regímenes patrimoniales del matrimonio y de las uniones de hecho. Lima: Gaceta Jurídica, 2002, pp. 378-381. 


\section{La regulación de la convivencia en el Código Civil}

Pese a que el legislador no ha tenido como intención instaurar un régimen de protección al concubinato, pues más bien su «ideal» es lograr su paulatina disminución y eventual desaparición (que quedará en simples deseos si se revisan las estadísticas), y no crear un matrimonio de segunda clase, ${ }^{73}$ el artículo 326 del Código Civil reconoce algunos efectos al concubinato "propio» o "perfecto", es decir, a aquel que satisface las notas referidas en el numeral anterior, que conviene explicar para tener una idea clara de los alcances de su regulación civil. ${ }^{74}$

\section{a) Relaciones personales entre los convivientes. ¿Se deben alimentos los concubinos?}

El mismo legislador, que fue reticente y retrechero con las familias no conyugales, no pudo evitar reconocer que las parejas no casadas se unen para forjar una comunidad de vida, desde el momento mismo en que el artículo 326 del Código Civil señala que la unión de hecho se decide para alcanzar finalidades y cumplir deberes semejantes a los del matrimonio.

Por ello, Bigio considera que el comportamiento de la pareja deberá ceñirse a las pautas generales que el Código señala respecto de las relaciones personales entre los cónyuges. Ello implicará, en línea de principio, fidelidad y asistencia mutuas (artículo 288), especialmente lo primero, dado que es usual perfilar la figura sobre la base de la exclusividad o monogamia.

Se ha dicho, siempre con relación al matrimonio, que, en el estatuto previsto para este, la indicación de los deberes principales entre los cónyuges, es decir, la consagración de estándares compartidos por la comunidad globalmente considerada en temas de solidaridad, asistencia, fidelidad, protección, responsabilidad social, etc., tiene un valor simbólico profundo y constructivo; y que la objeción derivada de lo que acontece en la práctica, que traiciona el modelo y, por tanto, amenaza de inefectividad las indicaciones del orden jurídico, no es determinante. Aquello que vale en tales órdenes — se asegura- es la "potencialidad", la actitud que puede devenir fuerza reguladora de la generalidad y de la normalidad de las relaciones

CORNejo Chávez, Héctor. Op. cit., pp. 66-67.

74 Efectos que se justifican excepcionalmente para no fomentarlas, como dicen ARIAS SCHREIBER, Max; Ángela ARIAS SCHREIBER, y Alex PLÁCIDO. Exégesis del Código civil peruano de 1984. T. VII: "Derecho de Familia». Lima: Gaceta Jurídica, 2002, pp. 263264. 
intersubjetivas. Si ello es así en el matrimonio, extender este tipo de deberes a la unión libre complica el panorama por atentar contra la reivindicación de autonomía que se manifiesta en esta. ${ }^{75}$

Discrepo abiertamente de tal apreciación. Nada obsta, en mi concepto, a que los convivientes esperen e, incluso, (aun sin mandato legal expreso) se exijan fidelidad, independientemente de que la violación de la misma no sea causa de disolución de la unión, dado que no se confiere al concubino ofendido ninguna acción sobre el particular, incluso si decidiera dar por concluida la cohabitación aun a costa de perder los derechos que la ley reconoce al conviviente que ha sido abandonado. Más allá de esta constatación, me parece saludable que entre quienes comparten una vida sin estar casados sea deseable un comportamiento ceñido a la lealtad, a la exclusividad, a la monogamia. Generalmente, se cree que este tipo de conductas solo son posibles en el matrimonio y no en las familias de hecho bajo el insólito argumento de que la libertad para ponerle fin relaja los patrones de conducta que se espera de la pareja.

En esta misma orientación, cabe preguntarse si los concubinos se encuentran «obligados» a hacer vida en común en el hogar de hecho que han constituido, tal como se exige a los cónyuges por mandato del artículo 289. Detengámonos un momento sobre este tópico.

Tengamos en cuenta que la obligación de vivir bajo un mismo techo no solo conlleva convivir en la misma casa, sino también cumplir (así se dice) el débito conyugal (sexual). ${ }^{76}$

Con agudez, Trazegnies se ha preguntado si el derecho puede obtener, con todos los medios a su alcance, que las obligaciones extrapatrimoniales de los cónyuges se cumplan. En referencia a la prestación sexual recíproca, advierte que los conflictos que se suscitan parecen imposibles de dirimir mediante un juicio. Comenta que, en los Estados Unidos, los jueces han creido inconveniente que el derecho ingrese a ese campo de las relaciones humanas. ${ }^{77}$

Siempre, con referencia a los cónyuges, el profesor Arechederra se interroga si los esposos están obligados a vivir juntos. Según la ley, sí, añade. Sin embargo, anota que, para la cultura actual, dicha exigencia resulta extraña, pues el matrimonio no implica sometimiento a un imperativo categórico. Por otro lado, anota que los comportamientos familiares son difícilmente reconducibles a las categorías jurídicas usuales. No deja de comentar que el

\footnotetext{
VITA, Ana de. Op. cit., pp. 170-171.

6 ARIAS SCHREIBER, Max; Ángela ARIAS SCHREIBER, y Alex PLÁCIDO. Op. cit., p. 170.

77 De TRazeGnies Granda, Fernando. Op. cit., p. 38.
} 
incumplimiento de dicha obligación se estrella contra la sustancia del matrimonio. ${ }^{78}$

Si trasladásemos, mutatis mutandi, estas apreciaciones a la convivencia marital sin nupcias, podríamos pensar, del mismo modo, que ese deber de cohabitación, aun siendo incoercible (nadie se imagina a la esposa o a la conviviente ante un Tribunal pidiendo el cumplimiento del débito sexual del consorte) por encontrarse ligado con la libertad de la persona, tiene un trasfondo irrefutable y fundamental: la affectio maritalis, especialmente en su dimensión interna (antes que externa, pero que tampoco es despreciable), es decir, más que la rigurosa observancia de un mandato legal (a todas luces de un alto grado de inefectividad en su actuación judicial), traduce la decisión de vivir como una familia verdadera, que no solo comparte afectos e ilusiones sino también la coexistencia diaria, con todo lo que ello implica. Si partimos desde esta óptica, no encuentro ningún inconveniente para hacer extensible el artículo 289 —en su primer enunciado únicamenteal concubinato.

El artículo 290 presenta menos resistencia en cuanto a su aplicación. Los concubinos tienen el derecho y el deber de participar en el gobierno del hogar de hecho que han conformado, así como decidir el lugar en el que residirán y decidir los temas atinentes a la economía del hogar. Si los cónyuges se encuentran en la posibilidad de elegir entre diversos regímenes patrimoniales (incluso si viven bajo un régimen de separación de bienes, en el que cada cual administra sus bienes) y ello no obsta a que participen en la economía de la casa, no existe ninguna objeción para que los covivientes determinen de modo conjunto lo que más les convenga en este terreno.

El artículo 291 requiere de cierta matización. De acuerdo con su primer párrafo, si uno de los cónyuges se dedica exclusivamente al trabajo del hogar y al cuidado de los hijos, la obligación de sostener a la familia recae sobre el otro, sin perjuicio de la ayuda y colaboración que ambos cónyuges se deben en uno y otro campo. Dejo a un lado el segundo párrafo, que, más bien, abordaremos al momento de analizar las consecuencias de la terminación de la unión paramatrimonial.

Creo que tanto en las familias matrimoniales como en aquellas parejas no pasadas, ni siquiera cuando existe acuerdo de separación de patrimonios, no se acostumbra a estipularse nada sobre la contribución de cada cual al hogar; mucho menos, en lo que respecta al cuidado de los hijos. Sería un trato extraño, al menos para una realidad como la nuestra. Pero esta

ARECHEDERRA, Luis Roberto. "El matrimonio informal (Nadie puede querer, lo que realmente quiere, sin quererlo)». En Diez años del Código Civil peruano. Balance y perspectivas. Lima: Universidad de Lima - W. G. Editor, 1995, p. 451. 
ausencia de pactos se ve suplida por el comportamiento de los consortes, pues es claro que, si uno de ellos deja el mercado laboral (y deja de producir para dicho mercado), a fin de dedicarse al trabajo del hogar (y dedicarse a la producción familiar en palabras de Posner), quien percibirá ingresos será aquel que labore fuera de la casa. Es elemental deducir, de ello, que el presupuesto, las necesidades y los gastos tendrán que ser atendidos con tales ingresos. Además, el que la pareja se dedique a las tareas del hogar no constituye un trabajo improductivo. Antes al contrario, quien permanece en la casa aportará su trabajo (aunque no sea remunerado, tiene un valor concreto: ya sea el precio que se tendría que pagar a alguien que venga de fuera; el precio de aquello a lo que renuncia a seguir haciendo fuera del hogar quien se ocupa de este; e, incluso, el precio de dejar a un lado el desarrollo profesional y de mantenerse apto para enfrentar la competencia del mercado laboral, pues la labor doméstica lo desengancha y desactualiza).

Creo que el sostenimiento por parte de quien trabaja fuera del hogar responde a la interrogante de si los concubinos se deben alimentos durante la convivencia. Y es que, como bien se ha observado, esta cuestión se plantea normalmente a la extinción de la unión de hecho, pues durante la convivencia la asistencia recíproca se producirá de modo espontáneo. ${ }^{79}$ Como dice Martínez Rodríguez, es más conveniente hablar de un deber de sostenimiento entre los convivientes en lugar de un deber de alimentos, siendo, incluso el primero, un deber más amplio que el de la obligación alimentaria.

Debido a la pobreza del Código, se puede dudar sobre la exigibilidad del deber de asistencia y, más precisamente, del deber alimentario. Creo, incluso, que el propio Código genera esta duda que podría derivar en una absurda doble contradicción.

En efecto, si los concubinos establecen una relación marital estable, no encuentro escollo para entender que la pareja se debe asistencia (como ocurre en Brasil gracias a la ley 9278, de 10 de mayo de 1996), en la medida que su relación se forja para alcanzar finalidades y cumplir deberes semejantes a los del matrimonio, como dice el propio artículo 326. Y el socorro mutuo es uno de dichos deberes. Pero si nos detenemos a analizar el caso concreto y particular del deber alimentario, es probable que lleguemos a la primera de las contradicciones a las cuales me refería, pues, dado que no existe norma o mandato especial, la conclusión es que los concubinos no están obligados a prestarse alimentos mientras conviven. Además, tampoco

79 Martínez RODRÍGuez, Nieves. "¿Están los convivientes de hecho obligados a prestarse alimentos?». En J. M. Martinell y M. ${ }^{a}$ T. Areces Piñol (eds.). Op. cit., p. 348. 
se encuentran comprendidos entre los obligados en el numeral 474 del Código. Sin embargo, si ellos lo han pactado de manera expresa, esos pactos son fuentes válidas de obligaciones sin más límites que los impuestos a la autonomía privada, ${ }^{80}$ ya sea durante o después de la cohabitación. ${ }^{81} \mathrm{Y}$ en ello soy terco en reconocer la absoluta admisibilidad de estos acuerdos, pues no son, en nada, contrarios al orden público.

El problema se plantea cuando no hay pacto. Sobre el particular, el Tribunal Supremo de España, mediante fallos del 21 de octubre de 1992, 18 de febrero de 1993 y 11 de octubre de 1994, ha tomado en cuenta no solo el acuerdo expreso, sino también aquellos hechos concluyentes que inequívocamente evidencian la voluntad de asumir la obligación alimentaria. Posiblemente se basó en el hecho mismo de la convivencia, pero, por si no bastara, se ha sugerido que, además de la vida en común, se debe evaluar la forma en que esta se ha desarrolado, ya sea porque uno de ellos asumió voluntariamente los gastos y el otro se dedicó solo al hogar o a apoyar a quien trabaja fuera del hogar abandonando un puesto en el mercado laboral, etc. ${ }^{82}$ Es posible que, para muchos, ello no baste y que, ante la carencia de una norma en concreto, se señale que podrá haber deber de asistencia mas no obligación alimentaria. A ello nos conduce la parquedad del Código.

La segunda contradicción que advierto, y que abordaré líneas abajo, es que la propia ley reconoce alimentos en caso de conclusión de la unión paramatrimonial cuando termina por la decisión unilateral de uno de los consortes, que abandona al otro.

En una curiosa sentencia de nuestra Corte Suprema del 7 de junio 1993, se señala que el cese de la unión de hecho no solo consiste en la terminación de la convivencia bajo un mismo techo, sino, aun si esta persiste, cuando uno de los concubinos se sustrae intencional y deliberadamente a las obligaciones emergentes de la unión de hecho. La Corte señala que, de acuerdo con el artículo 326 del Código, la decisión unilateral de uno de los convivientes de terminar la unión faculta al juez a conceder, a elección del abandonado, una indemnización o una pensión de alimentos. En el caso resuelto, la demandante exigía que el demandado la acudiera con una pensión alimenticia por haber terminado la unión de hecho de más de treinta años ininterrumpidos. El demandado, al salir a juicio, sostuvo que no era verdad que la unión hubiere cesado por cuanto seguía viviendo junto a la actora, en

\footnotetext{
8O MARTínez RoDríGuez, Nieves. Op. cit., p. 349.

81 PÉREZ UREÑA, Antonio Alberto. Uniones de hecho: estudio práctico de sus efectos civiles. Madrid: Edisofer, 2000, p. 92. Este autor, sin embargo, equipara el deber de asistencia con el deber alimentario.

82 Martínez Rodríguez, Nieves. Op. cit., pp. 350-351.
} 
el mismo inmueble. Frente a tal alegación, la Corte entendió que debía considerarse como cesación de la unión la sustracción de los deberes emergentes de la misma (que no precisa, en nada) por parte de uno de los convivientes al margen de que siguieran viviendo juntos y que nada le impedía señalar una pensión fija y permanente (sic), no obstante que el demandado pudiera estar acudiendo con una suma de dinero que resultaba exigua para subvenir las necesidades del otro. La Corte falló que el demandado asistiera a la actora con una pensión alimenticia adelantada del veinte por ciento de su haber líquido.

Esta sentencia contiene una serie de aspectos que vale la pena analizar. En primer lugar, el Supremo Tribunal alude a «deberes emergentes» de la unión de hecho que no detalla. Si quisiéramos forzar una interpretación no cabría otra que entender que se refiere a la asistencia recíproca que se deben los convivientes, a los cuales hemos considerado aplicable el artículo 288 del Código Civil. En segundo lugar, si la Corte hubiera tenido en cuenta que la asistencia constituye un deber de mayor cobertura que la obligación alimentaria, podría haber condenado al conviviente al pago de tal pensión sin incurrir en la ficción de dar por terminada la unión de hecho. El artículo 326 no autoriza a incluir como cese de un concubinato el que uno de los miembros de la pareja se sustraiga a sus deberes. Simple y llanamente, atendiendo al comportamiento que había observado el demandado por más de treinta años, debió derivar que el deber de asistencia que asumió voluntariamente había sido incumplido a partir de un cierto momento, pero debió deducir de tal comportamiento que su voluntad fue hacerse cargo de la situación económica de la actora y, por ende, obligarlo al cumplimiento del tanta vences mencionado deber de socorro. Pero, como su fallo concluye en la fijación de una pensión alimenticia, no pudo escapar al condicionamiento impuesto por el artículo 474, que no sanciona la prestación alimentaria para los convivientes more uxorio. A fin de encontrar una solución, que se amparase en el propio artículo 326, decidió considerar terminada la unión de hecho aun cuando siguiera habiendo comunidad de techo y no sabemos si de lecho, pero dudamos de que existiese a esas alturas.

Hace no mucho, exactamente mediante sentencia del 26 de setiembre de 2002 (en la casación 1637-2002), la Corte Suprema ha emitido un fallo sorprendente que empaña más el escenario. En efecto, en dicha ejecutoria, ha resuelto que el concubino abandonado por decisión unilateral tiene derecho a alimentos, pero que, cuando uno de ellos contrae matrimonio, cualquiere que fuere, incluso el abandonante, cesa dicha obligación alimentaria, dado que el Supremo Colegio entiende que, para que subsista el deber de asistencia a través de la pensión en cuestión, solo es exigible en tanto no 
exista impedimento matrimonial en ambos exconvivientes; de esta manera, aplican de manera indebida el artículo 326 del Código. Y digo indebida, pues, si no hay concubinato por mediar abandono, no se puede recurrir a la idea de la inexistencia de impedimento matrimonial, que únicamente es predicable en caso perviva la convivencia more uxorio, pero no cuando ha concluido. La Corte, curiosamente, ha olvidado, sin justificación, que los alimentos tienen como finalidad asistir a quien requiere de ayuda material y que, si el abandonante contrae matrimonio, ello no desaparece, como efecto mágico, las necesidades primarias del conviviente que fue abandonado. En mi concepto, el Tribunal ha dejado pasar una preciosa oportunidad para sentar una regla necesaria: el deber de alimentos entre concubinos y a favor de quien queda desamparado por el conviviente que decide apartarse del hogar común si quien es desatendido carece de los medios para subsistir.

\section{b) Las relaciones patrimoniales: la posibilidad de acuerdos privados entre los concubinos}

A partir de la Constitución de 1979, se reconoce que la unión de hecho genera una sociedad de bienes (así la calificó el artículo 9 de dicha Constitución) entre los convivientes, que se sujeta al régimen de la sociedad de gananciales en cuanto sea aplicable. La misma previsión proviene del artículo 326 del Código Civil. La actual Constitución, en cambio, se refiere a una comunidad de bienes (calificación más adecuada según Cornejo). ${ }^{83}$

A raíz de esta disposición, quienes se han ocupado del tema consideran que, cumplidos los requisitos que la ley exige al concubinato, se entiende configurada ipso iure esa sociedad (comunidad) de bienes. Además, se señala unánimente que los convivientes no pueden acogerse al régimen de separación de patrimonios, por cuanto el artículo 326 no dejaría opción para ello, por lo que el régimen patrimonial aplicable y obligatorio es el de la sociedad de gananciales. Solo los cónyuges pueden optar por uno u otro régimen. ${ }^{84}$ Pero, para ello, es necesario que transcurran los dos años exigidos por la ley, pues si no serán aplicables las normas sobre la copropiedad. ${ }^{85}$

83 Cornejo Chávez, Héctor. Op. cit., pp. 72-73. En idéntico sentido, Plácido, Alex. Op. cit., p. 45.

84 Así, ARIAS SCHREIber PEZET, Max. "El derecho de familia y los contratos. En La familia en el derecho peruano. Libro Homenaje al doctor Héctor Cornejo Chávez. Lima: Pontificia Universidad Católica del Perú, 1992, p. 272; ARIAS SCHREIBER, Max, Angela ARIAS SCHREIBER y Alex PLÁCIDO. Op. cit., p. 264; BIGIO CHREM, Jack. Op. cit., pp. 156-157; PLÁCIDO, Alex. Op. cit., p. 386.

85 PlÁCIDO, Alex. Op. cit., p. 386. 
Además, se sostiene que, una vez que surja tal comunidad de bienes, a la cual sean aplicables las reglas de la sociedad de gananciales (sin que se convierta en sociedad de gananciales), los concubinos no pueden variar de régimen patrimonial. ${ }^{86}$

Discrepo abiertamente de esta apreciación, aun cuando resulte unánime la posición contraria. Para ello, parto de la premisa de la inexistencia de prohibición sobre los pactos que pueden celebrar los convivientes para regular sus relaciones patrimoniales. Simple y llanamente la norma se aplica de manera supletoria en ausencia de pacto específico y solo en ese momento (cumplidos los requisitos de la unión de hecho) los bienes se presumirán comunes.

Los pactos patrimoniales entre concubinos, que tienen como fin garantizar recíprocamente los aspectos económicos de la convivencia, resultan ser válidos. ${ }^{87} \mathrm{Nada}$ nos indica que ellos sean nulos o inválidos.

Si descendemos a aquello que podría ser el contenido de tales convenios, podríamos incluir los acuerdos sobre la obligación recíproca de contribuir a la necesidad del menaje familiar, la puesta a disposición de los bienes que sean de uno o de ambos, la puesta a disposición de la propia capacidad laboral y los réditos que genere o la contribución que derive del trabajo doméstico ${ }^{88}$ la adquisición conjunta de bienes o la adquisición separada, sin desatender las necesidades del hogar. Incluso, no veo inconveniente para que se pacte la asistencia económica en caso de estado de necesidad por encontrarse la pareja imposibilitada de generar ingresos, ${ }^{89}$ aun después de la conclusión de la unión. También pueden estipularse reglas para la administración de los bienes o sobre el uso de la casa común cuando no exista más comunidad de techo. ${ }^{90}$

Es claro que los pactos a los cuales aludo (acompañados de una complementaria reforma del sistema de publicidad, cuando ello sea posible, si se les quiere hacer oponibles a terceros) se presentan como una mejor solución a la aplicación de un régimen legislativo ${ }^{91}$ que pretende ser asfixiante. Se trataría, sin duda, de contratos atípicos ${ }^{92}$ que posiblemente resolverían mejor

86 Ib., p. 387, quien da cuenta de que la misma solución ha sido observada por el Tribunal Registral de la Oficina de Lima y Callao mediante resolución 343-98-ORLC/TR del 30 de septiembre de 1999.

87 DotTo, Brunilla del. Op. cit., p. 889.

88 Ib., p. 891.

$89 \quad$ Ib., p. 892.

$90 \quad$ Ib., p. 896.

91 ASTONe, María. Op. cit., p. 1485; FERRANDO, Gilda. Op. cit., pp. 305 y 316-317.

92 Astone, María. Op. cit., p. 1487. 
las controversias patrimoniales entre los interesados por permitirles organizarse de manera adecuada y anticipada. Y que no se diga que no es conveniente ampararse en la doctrina italiana bajo el argumento de que, en Italia, al no existir normas para el concubinato, ha tenido que ser la Corte de Casación la que admita los pactos, mientras que, en el Perú, sí hay legislación al respecto. También son admitidos por el Supremo Tribunal en España. ${ }^{93}$ Lo que sostengo es que no veo impedimento, ni ilicitud ni inmoralidad para dar cabida a estos acuerdos. ¿Qué lo prohibe? ¿Una interpretación excesivamente literal del artículo 326 del Código? La sociedad de gananciales como régimen debería ser supletorio. ${ }^{94}$ Es la tendencia: así ocurre en Francia con el PACS, en algunas legislaciones autonómicas de España o en Bélgica.

En esta misma línea, considero admisible que los concubinos puedan sustituir o apartar la aplicación, en cuanto sea posible, del régimen de la comunidad de bienes, para lo cual podrían otorgar un documento en el cual den cuenta de aquellos bienes que adquirieron y estipular la forma en que liquidarán tal comunidad, los bienes que se atribuyen a cada cual, la manera en que se atenderán las deudas contraídas en interés común, etc.

Por ello, nos hemos despachado en contra de la ejecutoria del 10 de setiembre de 2002, emitida por la Corte Suprema, en cuanto considera que los pactos de separación de bienes entre concubinos no son admitidos por el Código Civil. ${ }^{95}$

\section{La indemnización y la concesión de alimentos al momento de la ruptura: una extraña e incomprensible confusión de conceptos y de las funciones de la pensión de alimentos y de la reparación civil}

El artículo 326 del Código dispone que la unión de hecho termina por muerte, ausencia, mutuo acuerdo o decisión unilateral. En este último caso — añade - el juez puede conceder, a elección del abandonado, una cantidad de dinero por concepto de indemnización o una pensión de alimentos, además de los derechos que le correspondan de conformidad con el régimen de la sociedad de gananciales.

\footnotetext{
PÉREZ UREÑA, Antonio Alberto. Op. cit., p. 72.

FERRANDO, Gilda. Op. cit., pp. 317-318.

VEGA MERE, Yuri. "Sobre el derecho de los convivientes a ordenar su patrimonio mediante acuerdos de separación de bienes y la urgencia de definir la llamada "sociedad de bienes» del concubinato. Y sobre la necesidad de modificar la jurisprudencia de la Corte Suprema». Diálogo con la Jurisprudencia, año 9, n. ${ }^{\circ}$ 60, septiembre, 2003, pp. 8394, Lima.
} 
Comencemos por lo menos complejo. Si la unión de hecho termina por muerte (natural, cerebral o presunta), el tema parece no crear mayores problemas, salvo que el conviviente no tendrá derechos sobre la herencia del consorte difunto. Si, en cambio, concluye por decisión acordada, es previsible que los interesados pongan fin al régimen de comunidad de bienes que la ley les impone. Y me pregunto: ¿puede ponerse fin a tal comunidad, a la cual se le aplica, en cuanto sea posible, el régimen de la sociedad de gananciales, por acuerdo privado, sin intervención del juez? Evidentemente, la respuesta es afirmativa y ello confirma el aserto de la plena admisibilidad de los pactos sobre el régimen económico.

En segundo término, es claro que la disolución que no se encuentra regulada por pactos ad hoc deberá seguir la suerte de la liquidación de la sociedad de gananciales en los aspectos patrimoniales. Es de esperarse que, si no existe acuerdo, las partes interesadas en reclamar alguna participación en los bienes adquiridos durante la convivencia deberán aportar las pruebas de su contribución a la adquisición de tales bienes.

Tal contribución, por lo demás, no debería implicar siempre y necesariamente acreditar la entrega de dinero (que es la mejor prueba) para tal o cual compra o inversión. También deben valorarse aspectos como la dedicación de uno de los cónyuges al cuidado del hogar y crianza de los hijos y su renuncia a participar en el mercado laboral y a abandonar oportunidades de desarrollo profesional y personal como una prueba de la contribución al esfuerzo común, al ahorro o a dejar al consorte en la posibilidad de que se dedique a labores fuera de la casa. La entrega al trabajo doméstico es valiosa por sí misma. No descarto casos en los cuales se acredite que los aportes respondan a proporciones no idénticas, en cuyo caso el juez deberá evaluar las variantes que he comentado, de modo complementario.

Si no existen mayores pautas que den lugar a que el juez establezca cuotas de participación diversa, es claro que los bienes adquiridos (en ausencia de pactos, por cierto) serán reputados como adjudicables a cada conviviente en una proporción similar. Así lo ha resuelto la Corte Suprema mediante sentencia del 21 de mayo de 1998, fallo en el cual el Tribunal, en un caso de cese por decisión unilateral de unos de los convivientes, decidió reconocer que a cada concubino correspondía la mitad del inmueble adquirido durante la convivencia. Sin embargo, no se debe olvidar que, para ello, las cortes superiores, mediante acuerdo 8 del Pleno Jurisdiccional de Familia del año 1998, entienden que, previamente a la liquidación, debe encontrarse acreditada (en previo proceso) la convivencia. ${ }^{96}$

96 Plenos jurisdiccionales que, sin embargo, no tienen carácter vinculante, pues nada dice al respecto la Ley Orgánica del Poder Judicial, por lo que su único propósito es dar 
Mayor dificultad presenta la solución prevista en el numeral 326 cuando la cohabitación cesa por decisión unilateral de uno de los convivientes. En este caso, la ley establece que, sin perjuicio de los derechos que resulten de la aplicación de las normas sobre el régimen de la sociedad de gananciales, el concubino abandonado tiene derecho — según el Código- a una indemnización o a una pensión alimenticia. ¿Son excluyentes ambos conceptos? ¿Acaso cumplen la misma finalidad?

Respecto de la indemnización, la escasa doctrina es bastante concisa. Mientras Cornejo no dice nada, Plácido señala que tal reparación se ordena como consecuencia de la frustración del proyecto de vida, la aflicción de sentimientos, etc. ${ }^{97}$ Parece que Plácido encuentra como fundamento de dicha indemnización la mitigación del daño a la persona o del daño moral, aunque por cierto, en un trabajo reciente, amplía el elenco de los daños resarcibles.

Creo que la norma va más allá. En efecto, la disolución por ruptura unilateral — sin perjuicio de la liquidación de la comunidad de bienes- no solo causa perjuicios personales o morales. También puede causar daños de orden material, pero luego regresamos sobre este tema.

El problema que suscita la norma tiene que ver con la disyuntiva con la que se sancionan los derechos ya sea a una pensión alimenticia o bien a una indemnización, independientemente de las reglas sobre la liquidación de la denominada sociedad o comunidad de bienes, que, por cierto, puede tener algún nivel de gravitación.

En efecto, si consideramos que la alternativa planteada por la norma implica que el juez debe conceder una u otra cosa, olvidamos que la pensión alimenticia y la indemnización cumplen funciones del todo distintas. La primera tiene como fin asistir al abandonado por las posibles carencias que enfrentará cuando el conviviente se aparte del hogar y prive al primero de los medios para su subsistencia. La segunda, por el contrario, apunta a reparar el daño, personal o eventualmente patrimonial, producto de la decisión de dar por concluida la relación convivencial que, sin duda, puede tener efectos sobre las emociones, sobre la autoestima, sobre los proyectos de vida construidos a lo largo de la vida compartida en el tiempo. Pero la norma no parece aceptar estas diferencias incontrastables.

Con relación a la pensión alimenticia, explica Cornejo que esa no fue la propuesta que formuló como miembro de la Comisión Reformadora del

uniformidad a los criterios seguidos por las cortes superiores, según comenta Federico Mesinas Montero en la Presentación del volumen Guía rápida de jurisprudencias vinculantes y Acuerdos Plenos Jurisdiccionales. Lima: Gaceta Jurídica, 2002, pp. 5-9.

97 PLÁCIDO, Alex. Op. cit., pp. 398-399. 
Código Civil de 1936, pues la concesión de tal pensión le parece excesiva porque implica una modificación del artículo 474 del Código vigente que va más allá de la Constitución y consolida una forma de vida que, para él, no es merecedora de estímulo. ${ }^{98}$ En rigor, el derecho a una pensión alimenticia en caso de abandono fue introducido por la Comisión Revisora (que estudió las propuestas de la Comisión Reformadora).

Sobre el particular, Bigio, que integró la Comisión Revisora, comenta que, durante los debates de esta parte del numeral, el doctor Carlos Montoya Anguerri, entonces vocal de la Corte Superior de Lima, propuso a dicha Comisión que el derecho a pedir alimentos no solo debía ser exigible entre personas que tuvieran vínculo de parentesco o de familia. Montoya expresó que consideraba justo que quienes habían vivido como marido y mujer sin estar casados, si se les reconocía derecho a los bienes, con mayor razón debían, en caso de abandono, tener derecho a alimentos. Además, señaló que el derecho a pedir alimentos tiene una vía expeditiva mucho más rápida que la acción indemnizatoria y otorga al interesado una asignación provisional de alimentos. Bigio apoyó la propuesta dada la frecuencia del concubinato en el país. Otro miembro de la Comisión Revisora, el doctor Haya de la Torre, manifestó que, en muchos casos, la pensión alimentaria podía ser más justa y necesaria que una indemnización, que, por recibirse una sola vez, podía ser administrada de forma inapropiada por el interesado. ${ }^{99}$

La exposición que relata Bigio da a entender que la pensión fue acogida como una alternativa por razones de celeridad procesal y de una presunta dilapidación de la suma que se recibiere como reparación. Si bien se trataba de una interesante tutela de urgencia, ello no debió cerrar la puerta a una complementaria indemnización en caso de que el abandonado acreditase daños derivados de la ruptura causada por quien se marchó del hogar.

Por otro lado, y siempre bajo nuestra posición favorable a los pactos entre los concubinos para regular sus relaciones personales y especialmente las patrimoniales, no veo inconveniente para admitir el pacto destinado a regular la prestación alimentaria a cargo de quien decide retirarse del hogar, sin perjuicio de los acuerdos indemnizatorios o de discutir la reparación en la vía judicial si no existiese ningún convenio al respecto. ${ }^{100}$

La pensión alimenticia tiene una fundamentación muy diversa a la reparación de posibles daños. Empecemos por decir que, cuando se termina la

98 CORNejo ChÁvez, Héctor. Op. cit., pp. 72-73. Sin duda, me muestro totalmente lejano de una posición tan férrea como la de este autor, que desconoce la necesidad de asistir al concubino abandonado.

99 BIGIO CHREM, Jack. Op. cit., p. 161.

100 Martínez RodríGuez, Nieves. Op. cit., pp. 352-353. 
unión de hecho que motiva el abandono, los afectos concluyeron, pero eso no inhibe ni deja de hacer exigible un mínimo deber de solidaridad de quien deja el hogar. Empero, el juez deberá valerse de argumentos concretos, puntuales, sólidos, que superen la dimensión moral del deber de solidaridad, basándose, al efecto, de la comprobación de las reales necesidades del abandonado y de la capacidad económica del concubino que puso fin a la unión.

Pero el tema no queda allí. ¿Cuánto tiempo va a ser exigible esa pensión alimenticia entre convivientes? Recordemos que el primer párrafo del artículo 350 del Código Civil establece que, por el divorcio, cesa la obligación alimenticia entre marido y mujer. Sin embargo, el segundo párrafo de esta norma prescribe que, si el divorcio se declara por culpa de uno de los cónyuges y el otro careciere de bienes o de gananciales suficientes o estuviere imposibilitado de trabajar o de subvenir a sus necesidades por otro medio, el juez le asignará una pensión alimenticia no mayor de la tercera parte del culpable. ¿Qué solución debemos observar para el caso del concubinato?

Ya hemos visto cómo, con la sentencia del 26 de setiembre de 2002 (en la casación 1637-2002), la Corte Suprema ha fijado una posición poco elaborada. Con dicha ejecutoria, el tribunal ha resuelto que el concubino abandonado por decisión unilateral tiene derecho a alimentos, pero que, cuando uno de ellos contrae matrimonio, cualquiere que fuere, incluso el abandonante, cesa dicha obligación alimentaria, dado que el Supremo Colegio entiende que el deber de asistencia solo es exigible en tanto ambos (ex) convivientes no tengan impedimento matrimonial. Con esta decisión, la Corte Suprema ha desconocido la función que cumplen los alimentos y ha consagrado una salida de escape al deudor alimentario, lo que deja en el desamparo al abandonado, bajo un argumento reñido con lo que dice la propia norma, dado que la ausencia de impedimento solo aplica cuando la convivencia pervive.

En nuestra opinión, los alimentos deben prestarse mientras el abandonado carezca de medios para subsistir sin importar si el conviviente que se alejó de la vivienda común contrajo matrimonio o no. Otra cosa será discutir el quantum frente a las nuevas obligaciones asumidas por el exconviviente que celebró nupcias con un tercero. ${ }^{101}$

Es fácil advertir que, para condenar al abandonante al pago de una pensión, seguimos razonando en términos de culpabilidad, pero ello no oculta

101 Para ESPINOZA ESPINOZA, Juan. "La necesaria parificación constitucional entre la unión de hecho y el matrimonio». Legal Express, año 2, n. ${ }^{\circ} 19$, julio, 2002, p. 8, Lima, no solo debería concederse alimentos cuando haya ruptura por decisión unilateral, sino también cuando el conviviente carezca de medios para subsistir. 
las reales necesidades del abandonado. Por ende, creo que, para determinar el monto y la propia duración de la pensión en el tiempo, es útil recurrir al artículo 350 del Código Civil.

Si el abandonado no acredita ninguna de las situaciones referidas en el numeral 350, la pensión debería ser simbólica y muy limitada en el tiempo. Si las acredita, pero el obligado demuestra que el beneficiario de la pensión ya no la requiere, se debe ordenar la extinción de la obligación sin la posibilidad de que se active de nuevo. Es conveniente recurrir, en este caso, al primer párrafo del artículo 483 del Código Civil. Y ello es así con mayor razón en la medida que no estamos ante cónyuges sino ante exconvivientes.

También debe extinguirse la obligación cuando el exconcubino abandonado contrae nupcias o mantiene una nueva relación de hecho, pues será el nuevo consorte quien deberá asumir tal deber. ${ }^{102}$ Distinta solución se podrá obtener si quien se casa o forma un nuevo hogar convivencial es quien abandonó a su anterior compañero (a), pues, si el abandonado todavía requiere de asistencia, la obligación perseguirá al antiguo concubino, lo que puede afectar la sociedad de gananciales que tenga el abandonante con terceros o sus bienes propios si optó por el régimen de separación de patrimonios. ${ }^{103}$

A su turno, la indemnización derivada del abandono no puede tener como objeto garantizar de por vida la colmación de las necesidades del abandonado. Si este obtiene ingresos o contrae matrimonio de modo que pueda ver atendidos sus requerimientos, los daños que pudiere haber sufrido no desaparecerán ni merecen ser perdonados al abandonante. Ello es algo que parece haber olvidado la Comisión Revisora.

La indemnización, por otro lado, solo podría reemplazar o hacer innecesaria la pensión alimenticia si aquella se extendiese a conceptos indemnizables diversos a los daños (generalmente morales) que padece el conviviente abandonado. Y aquí me quiero servir de la llamada indemnización compensatoria de la legislación española, tanto del Código Civil hispano para los matrimonios como de la legislación autonómica de Cataluña sobre parejas estables. ${ }^{104}$

\footnotetext{
102 PLÁCIDO, Alex. Op. cit., pp. 399-400.

103 Ib., p. 400.

104 Sobre la cual puede verse ZAMBRANO, Virginia. «Parejas no casadas e tutela del convivente. L'esperienza spagnola e la Llei Catalana 10/1998». En Francesca Brunetta d'Usseaux y Antonito d'Angelo (eds). Matrimonio, matrimonii. Milán: Giuffrè, 2000, p. 393 y ss.; y VEGA MERE, Yuri. "La eclosión de las legislaciones protectivas de las uniones homosexuales». Op. cit., pp. 249-253.
} 
La ley catalana de 1998 establece una interesante compensación económica al término de la convivencia a favor de aquel que, sin retribución o con retribución insuficiente, haya trabajado para el hogar común o para el otro conviviente, cuyo fin es atender una eventual situación de desigualdad entre el patrimonio de los dos miembros de la pareja que implique un enriquecimiento injusto y, además (creo), para poder subvenir los requerimientos de quien carece de una fuente de ingresos. La idea me parece fascinante debido a que no siempre, al momento de liquidar la comunidad de bienes, los jueces considerarán que la dedicación de uno de los cónyuges al hogar le significará una pérdida de oportunidades que podría tener consecuencias negativas al momento en que el abandonado ya no cuente con los ingresos de quien aportaba al hogar de hecho. Además, encaja, en mi opinión, con el sentido de que tendría la indemnización a la que se refiere el artículo 326, debido a que, solo en este caso, no se la limitaría a la simple reparación del daño personal o del daño moral, sino que, asimismo, englobaría el deber de asistencia, pero siempre dentro de la causa del cese de la unión: el abandono, que, curiosamente, no es el supuesto de las leyes españolas antes referidas.

Si fuera necesario recurrir a la legislación nacional para buscar alguna apoyatura, entendería que la modificación del régimen del divorcio para introducir la disolución del vínculo por mediar separación de hecho (inciso 12 del artículo 333 del Código Civil) introdujo una interesante vía de exploración. En efecto, además de que quien invoque la separación de hecho debe encontrarse al día en el cumplimiento de sus obligaciones alimentarias u otras que hubieren sido pactadas de común acuerdo por los cónyuges y del deber del juez de velar por la estabilidad económica del cónyuge e hijos que resulten perjudicados por dicha separación, el artículo 345-A establece, como una obligación del juez, el señalar una indemnización por daños, incluido el daño personal, u ordenar la adjudicación preferente de bienes de la sociedad conyugal, independientemente de la pensión alimenticia que le pudiere corresponder. ${ }^{105}$

En otras palabras, y aunque restringida erróneamente al supuesto de la separación de hecho, la norma apenas aludida diferencia claramente entre la indemnización de daños, que se pagaría con una suma capital (ya sea el daño personal ${ }^{106}$ o bien el patrimonial, o ambos) o con una separación no proporcionada de los bienes gananciales (para reparar el daño patrimonial),

105 Indemnización que, tal como lo ha resuelto la Corte Suprema con la ejecutoria del 11 de julio de 2003 (casación 600-2003), debe ser establecida obligatoriamente por el juez.

106 Es decir, la pena, el sufrimiento, la aflicción, el padecimiento; casi siempre se tratará de un daño moral o bien un daño psicológico, que es ya un estado patológico que supera el sufrimiento para comprometer la salud y transformarse en un auténtico daño a la persona. 
y la pensión alimenticia, que tiene como fin garantizar la subsistencia del mismo cónyuge que es indemnizado. ${ }^{107}$

La misma lógica debe observarse al momento de interpretar y aplicar el artículo 326 del Código para la unión de hecho en el caso de abandono. El conviviente que no decidió la separación debe ser asistido con la pensión alimenticia que asegure su sobrevivencia, pero también se le debe reparar los daños que sufra, ya sea tomando parte mayor de los activos que conforman la comunidad de bienes o bien condenando al abandonante al pago de una suma capital como resarcimiento. Esta es la única solución justa que los jueces deben consagrar.

El operador, el intérprete, debe tomarle el pulso a la realidad de lo que acontece en la familia y no cerrar los ojos ante el abrumador porcentaje de hogares en los que uno de los convivientes padece el abandono sin importar si existe o no un convenio matrimonial entre los concubinos. No podemos seguir callando que el silencio del legislador es cómplice de situaciones injustas y que, para ello, atañe al juez dar una lectura recreativa y pacificadora al ordenamiento legal.

\section{Y, si la ruptura se produce por obra de un tercero, ¿tiene el convi- viente derecho a la indemnización por muerte de su concubino?}

Comentan Mécary y Levoy-Forgeot que, en 1937, la Cámara Civil de la Corte de Casación francesa rechazó la demanda de indemnización de una concubina que había emplazado al responsable de la muerte de su compañero. La Corte consideró que era indispensable exhibir un interés legítimo jurídicamente protegido para obtener la reparación, cuestión que no se había dado, pues la actora vivía fuera de matrimonio (único modelo legitimador de la familia, como hemos dicho). Después de más de veinte años, en 1959, la Cámara Penal (o Criminal) de la misma Corte admitió la indemnización siempre que el concubinato fuera estable y no adulterino.

Fue necesario esperar hasta el 27 de enero de 1970 para que la Cámara Mixta de la Corte de Casación (lo que en el Perú sería un Pleno Casatorio) unificara los criterios de ambas salas y admitiera la indemnización a favor

107 Además, como ha sido precisado adecuadamente por PLÁCIDO, Alex. "La obligación del Órgano Jurisdiccional de velar por la estabilidad económica del cónyuge perjudicado por la separación de hecho». Diálogo con la Jurisprudencia, año 9, n. 67 , abril, 2004, p. 45 y ss., especialmente 49-54, Lima, el cónyuge a cuyo favor se fija la reparación debe ser quien no motivó la separación. 
del conviviente supérstite por la pérdida de su consorte aun cuando este hubiere estado casado. ${ }^{108}$

En Italia, el panorama es similar, pues, en este país, la Corte de Casación, mediante fallo del 27 de octubre de 1994, ha considerado que,

dado que el daño sufrido por el tercero [daño moral] es excepcionalmente resarcible bajo el único presupuesto de haber sido «causado» por un hecho ilícito penalmente calificado, la tutela resarcitoria debe fundarse en una relación de interés del tercero con el bien protegido con la norma incriminatoria, argumentable, en vía de inferencia empírica, en base a un estrecho vínculo familiar (o parafamiliar), como la convivencia more uxorio. ${ }^{109}$

En nuestro medio, Espinoza ha reclamado el mismo derecho a favor del concubino, bajo la argumentación de que la conviviente, ante tal lesión, es titular de un interés legítimo que no puede quedar desamparado, basándose en el artículo 4 de la Constitución, que protege a la familia sin distingos basados en el vínculo matrimonial. ${ }^{110}$

En todo caso, debe tenerse presente dos cuestiones: a) no solo se debe reparar el daño moral, sino también la privación del sustento del conviviente, de modo que no quede desamparado; y, b) para ello, será indispensable modificar el artículo VI del Título Preliminar del Código Civil, que limita la acción sustentada en el interés moral (no así el económico, lo que ya es bastante para reclamar el resarcimiento por la pérdida de los ingresos del concubino muerto) al agente (actor) y a su familia, dentro de la cual el Código no incluye a los convivientes.

108 MÉCARY, Caroline y Flora LeVOY-FORGEOT. Op. cit., pp. 85-86.

109 FERRANDO, Gilda. Op. cit., p. 305 (nota 13).

110 ESPINOZA ESPINOZA, Juan. Op. cit., p. 9 